\title{
Techno-Economic Analysis of a Stand-Alone Hybrid System: Application in Donoussa Island, Greece
}

\author{
Michail Katsivelakis ${ }^{1, *(D)}$, Dimitrios Bargiotas ${ }^{1}$, Aspassia Daskalopulu ${ }^{1}$, Ioannis P. Panapakidis ${ }^{1}$ \\ and Lefteri Tsoukalas ${ }^{2}$ \\ 1 Department of Electrical and Computer Engineering, University of Thessaly, 38221 Volos, Greece; \\ bargiotas@uth.gr (D.B.); aspassia@uth.gr (A.D.); panapakidis@uth.gr (I.P.P.) \\ 2 School of Nuclear Engineering, Purdue University, West Lafayette, IN 47907, USA; tsoukala@purdue.edu \\ * Correspondence: katsivel@uth.gr; Tel.: +30-6989368949
}

check for updates

Citation: Katsivelakis, M.; Bargiotas, D.; Daskalopulu, A.; Panapakidis, I.P. Tsoukalas, L. Techno-Economic Analysis of a Stand-Alone Hybrid System: Application in Donoussa Island, Greece. Energies 2021, 14, 1868. https://doi.org/10.3390/en14071868

Academic Editor: Tek Tjing Lie

Received: 8 March 2021

Accepted: 25 March 2021

Published: 28 March 2021

Publisher's Note: MDPI stays neutral with regard to jurisdictional claims in published maps and institutional affiliations.

Copyright: (c) 2021 by the authors. Licensee MDPI, Basel, Switzerland. This article is an open access article distributed under the terms and conditions of the Creative Commons Attribution (CC BY) license (https:// creativecommons.org/licenses/by/ $4.0 /)$.

\begin{abstract}
Hybrid Renewable Energy Systems (HRES) are an attractive solution for the supply of electricity in remote areas like islands and communities where grid extension is difficult. Hybrid systems combine renewable energy sources with conventional units and battery storage in order to provide energy in an off-grid or on-grid system. The purpose of this study is to examine the techno-economical feasibility and viability of a hybrid system in Donoussa island, Greece, in different scenarios. A techno-economic analysis was conducted for a hybrid renewable energy system in three scenarios with different percentages of adoption rate $(20 \%, 50 \%$ and $100 \%)$ and with different system configurations. Using HOMER Pro software the optimal system configuration between the feasible configurations of each scenario was selected, based on lowest Net Present Cost (NPC), minimum Excess Electricity percentage, and Levelized Cost of Energy (LCoE). The results obtained by the simulation could offer some operational references for a practical hybrid system in Donoussa island. The simulation results confirm the application of a hybrid system with $0 \%$ of Excess Electricity, reasonable NPC and LCoE and a decent amount of renewable integration.
\end{abstract}

Keywords: stand-alone hybrid system; HOMER Pro; simulation-optimization; techno-economic analysis; excess electricity percentage; Net Present Cost (NPC); Levelizez Cost of Energy (LCoE)

\section{Introduction}

Electricity power is vital for people's daily life, social and economic development during the centuries. Power systems typically include four components, that correspond to the four main issues, namely generation, transmission, voltage transformation, and consumption. In some remote areas like islands, villages and farms it is difficult to construct transmission and distribution system for such a small demand of electricity. As a result, there are people all over the world not having access in electricity. Greece is a Mediterranean country with the unique characteristic of having about 6000 islands, of which only a few hundred are inhabited. Greek islands have great potential for renewable energy sources (RES). However, only a percentage of almost $10 \%$ of the total installed renewable capacity is included on non-interconnected islands (NIIs). In addition, non-interconnected islands have small power systems, thus are dependent on Autonomous Power Systems (APS) which are considered both expensive and not environmentally friendly (since they consume diesel or heavy oil (mazut)). The weighted average of the variable cost for all the Greek NIIs electrical systems was rated at 130.519€/MWh, between 2014 to 2017 [1] and hence it is extremely high. The interconnection of all Greek islands with the mainland grid is an expensive project, but remains a high priority issue for government's energy policy.

The feasible solution to the high costs of electricity production and the reliable supply of electricity in NIIs are hybrid systems. The main objective of this paper is the design of an off-grid, autonomous hybrid system/microgrid for the electrification of Donoussa island, Greece. Based on the load profile of Donoussa island different schemes/scenarios of 
hybrid renewable energy systems are examined, using HOMER Pro software. Three main scenarios are examined with different percentage rate of renewable energy penetration. The optimal hybrid system configuration of each scenario is selected based on Excess Electricity parameter, Net Present Cost and Levelized Cost of Energy.

\section{Literature Review}

Because of the broad research and potential for application there is a wide range of published literature and specifically there are studies that examine the optimal design of a hybrid system via HOMER software for Greece. The study in [1], reviews the autonomous electricity systems deployed on Greek islands and examines different scenarios for the purpose of re-structuring the autonomous power system of Astypalea, aiming to reduce energy production costs in a sustainable way. Ref. [2] explore the sustainable planning of a renewables-based energy system aiming to replace the existing diesel generators with a wind-pv-hydrogen hybrid system in Karpathos island, Greece. In addition, authors in [3] explore the potential deployment of aRES-hybrid system for a small Greek island (Agios Efstratios) in three different case scenarios. They aim to establish the optimal design of the microgrid with the less effective cost through a techno-economic analysis. A study on the island of Lesvos, Ref. [4] explores the pumped hydro storage renewable energy system using a computational algorithm and concludes that $25 \%$ of the island's energy demand can be met by renewable energy systems in an economical manner. All studies mentioned above used HOMER software for optimization and simulation. Furthermore, a technical and economic study of a hybrid power plant, towards $100 \%$ electricity production is discussed in [5], for the autonomous island of Sifnos, Greece, in the context of the initiative of the Sifnos Island Cooperative (SIC) towards energy independence and sustainable development for the local community. In [6] there is a reference to a HRES in Fournoi island, in the eastern Aegean sea, which uses hydropower in order to generate electricity and to cover drinking and agricultural irrigation demands through desalination of sea water. The operation of a pilot hybrid power system using as storage devices sodium sulfur $(\mathrm{NaS})$ batteries, as part of the autonomous power system of Samos Island, is studied in [7]. A flexible power plant is modelled in [8], associated with a Multi-Objective Particle Swarm Optimization to obtain the optimal size of each plant component and the configuration located in Tilos islands, Greece. Finally, [9] analyses and models a generic hybrid power system installed on the island of Crete, Greece.

Besides Greece, there are many other studies that examine the feasibility on hybrid energy systems on islands. In [10] HOMER software is used to determine the most cost effective configurations of a hybrid autonomous energy generation system on St. Martin's island in Bangladesh. Moreover, Refs. [11,12] highlight a hybrid system composed of wind turbines, solar PV, diesel generators, micro-hydro plant and batteries in order to cater for the electricity demand of the Calayan island in the Philippines and Fiji islands respectively. In [13] the technical and economical viability of hybrid energy system in the Masirah Island power system in Oman is examined through HOMER and DIgSILENT software. A study in [14] discusses the techno-economic evaluation of a $100 \%$ renewable hybrid system on a remote island. The research in [15] proposes a mathematical model to analyze the effect of varying saturation for a hybrid PV-wind-battery system for Jiuduansha island near Shanghai. Moreover, authors in [16] use linear programming or optimal design of hybrid power generation system where conventional units and renewable energy generators are integrated in order to supply electricity to islands isolated from the national grid. In [17], at Sebira Island system, Kepulauan, a hybrid system implementation planning, following optimal sizing as well as an operational strategy of hybrid PV-Diesel-battery storage system is presented. Authors in [18] propose the design of a hybrid wind-solar-fuel cell power plant along with a power management strategy for TUNeIT [TUNisia and ITaly] Project, in which of four artificial islands are implemented in order to connect Bon (Tunisia) and Pizzolato (Sicily). Besides the off-grid and autonomous applications, grid-connected hybrid 
systems are examined. In [19] an optimal off-grid and a grid-connected hybrid system is proposed to cover the load demand of Bozcaada island, Turkey.

As mentioned earlier hybrid systems provide electricity not only on islands but in remote areas, communities, houses and buildings (schools, university campus, etc.). Fortunately, remote areas typically possess a wealth of locally available renewable energy resources. In [20-23] microgrids for the support of university buildings, academic institutions, university campuses and of an electric machinery laboratory are examined. The study in [24] employs MATLAB/Simulink and HOMER software to produce a techno-economic analysis and optimum design for a hybrid grid-independent system for the residential and agricultural requirements of an energy poor community in India. Another study proposes Cuckoo Search, a new metaheuristic algorithm, for the solution of the hybrid energy system optimization problem in a remote area located in Almora district of Uttarakhand, India [25]. Refs. [26-30] carry out analyses of off-grid microgrids for the electrification of remote areas in Greece, Cameroon, Nigeria and Malaysia.

Some of the studies mentioned above were employed in remote areas with no access to electricity, others to support buildings and others for islands. The design of each hybrid system is different and is dependent on the available climatic data and load profile in each different case study. There are only a few studies which take into consideration the excess electricity factor for the optimum design and the techno-economic analysis for the hybrid system. Excess electricity is a very important parameter which defines the stability, the reliable supply of the system and the economic viability of a hybrid system. In [31] the authors aim to investigate the existence of excess electricity in an isolated hybrid system in Nepal and discuss the impact of excess electricity on the hybrid system's cost and performance. To address this flaw, this work aims for the optimal design of hybrid system for a non-interconnected island in Greece (Donoussa) with the minimum percentage of Excess Electricity and the most cost-effective NPC and LCoE. In general, there are no specific studies in small or large islands with great fluctuations in their load demand. More specifically, this paper examines the techno-eonomically feasibilty and viability of a hybrid system in Donoussa island with different load demands depending on the season, with high load demands during season months.

\section{Methodology, Modelling and Optimization of the Hybrid System \\ 3.1. Methodology}

The methodology adopted in the present paper is depicted in Figure 1. The extraction of the optimal configuration is formulated as an optimization problem. This problem includes the objective function, decision variables and limitations. The methodology is composed by the following stages:

\section{Stage 1: Data collection}

The sizing of the hybrid system is based on the load characteristics, i.e., peak load and daily load profile. The peak load determines the minimal installed capacity of the hybrid system. For instance, the total power of the PV system should be greater than or equal to the peak load. The seasonality of the load profile determines the evolution of generation profile within the year. The meteorological data determines the availability of the renewable energy resources units. The technical data relate to the operational characteristics of the units. The economic data refer to the economic landscape of the country. For instance, the nominal discount rate is influenced by the state of the country's economy. Finally, the financial data refer to the installation, operation and maintenance costs of the units.

\section{Stage 2: Formulation of the optimization function}

It refers to the Net Present Cost (NPC). The scope is to serve the load during all the period of the techno-economic analysis. The limitations of the optimization problem refer to operational constrains of units, for instance restrictions to the operational hours due to scheduled maintenance within the year. The decision variables are the installed power of 
each units. Thus, the scope of the analysis is to define which combination of the hybrid systems, i.e., the exact configuration of generation units, leads to lower NPC during the technical lifetime of the installation.

Stage 3: Analysis of the results

The results are distinguished to optimization results results. The optimization results provide a hierarchy of all candidate combinations. The combinations are sorted based on the NPC that result to.

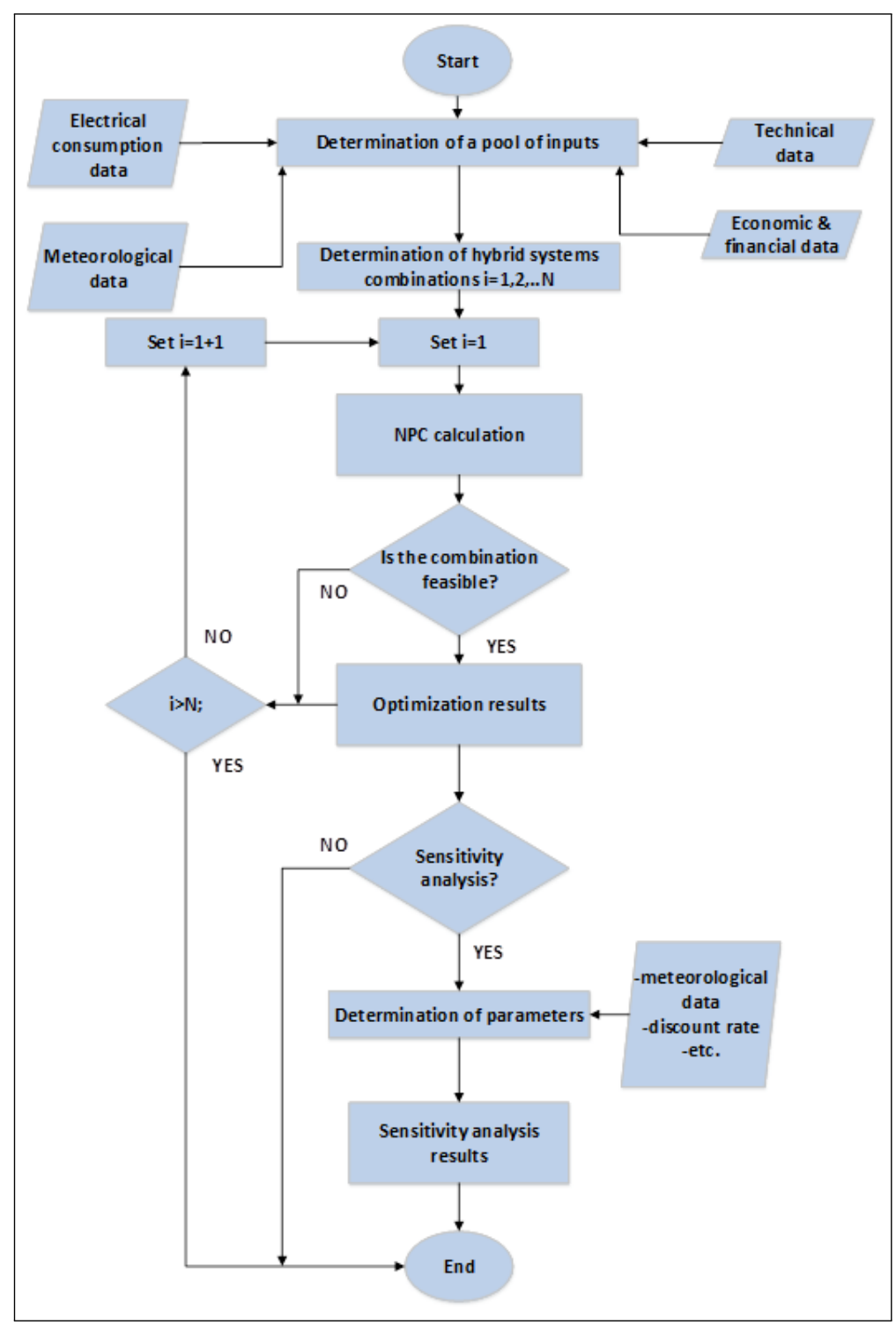

Figure 1. Flow-chart of the methodology.

\subsection{Donoussa Island's Electricity Load and Existing Power System}

Donoussa island is a small Greek island situated in the Aegean Sea, in the southeastern Cyclades. Donoussa's permanent population is 167 , according to the last census. The island is a tourist destination, during the summer months resulting in increased energy demands during this period. In the HOMER modelling tool the first parameter that has to be imported is the electricity load. The load profile for Donoussa island was retrieved from HEDNO (Hellenic Electricity Distribution Network Operator), at an hourly base for the year 2017. Figure 2 shows the annual electric load of Donoussa and the variation of the electricity load during the day. There is a peak in the electrical load of $450 \mathrm{~kW}$ in August and the average consumption of the island is $3460.30 \mathrm{kWh} /$ day with an average load of 
$144.18 \mathrm{~kW}$. In general, the increases of load are observed during the period from July to September, which is the high season of tourism.

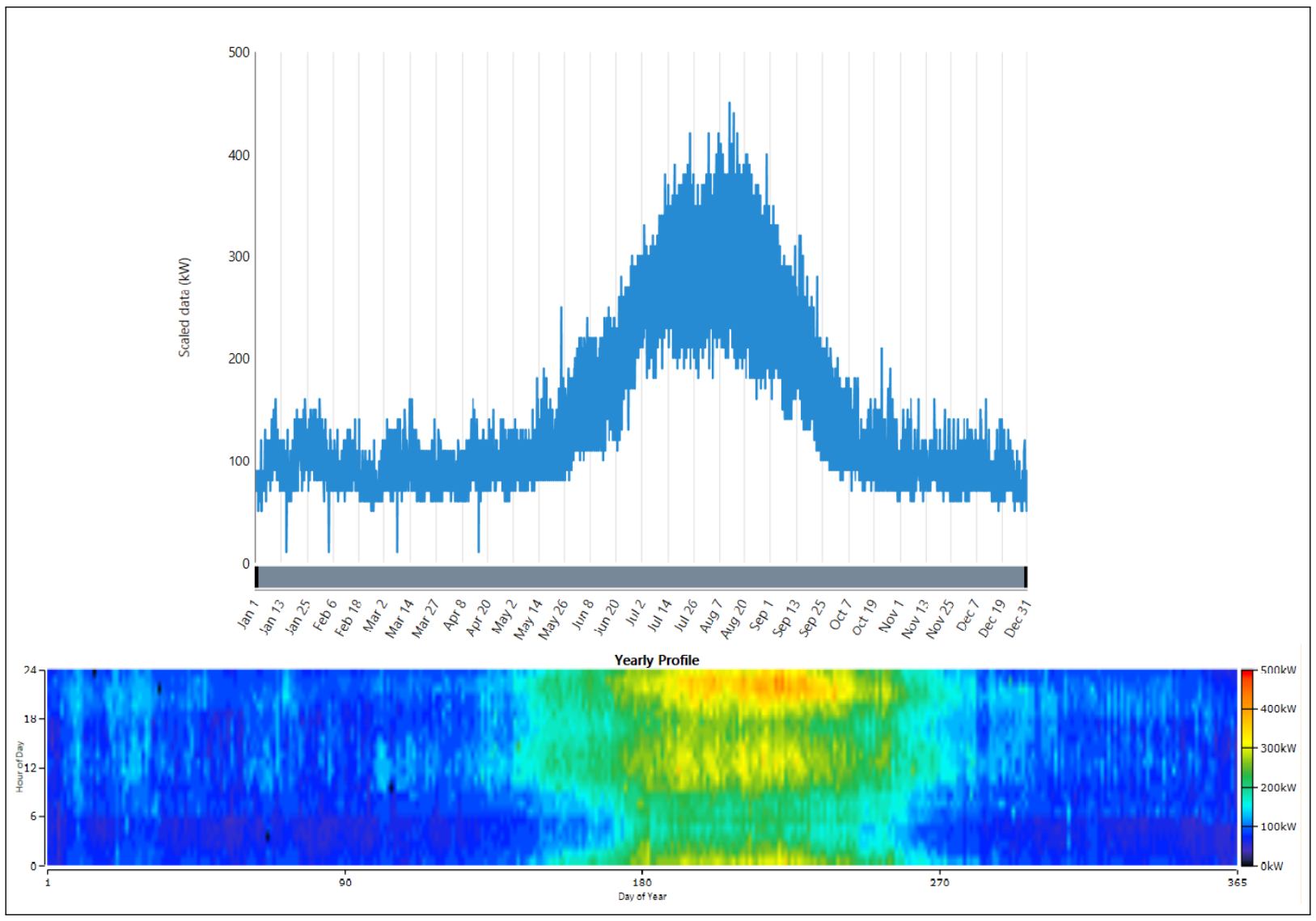

Figure 2. Annual load of Donoussa and Data-Map of the monthly load profile.

Donoussa is one of the 32 greek NIIs. Its energy system is mainly based on one diesel power plant for the production of electricity, without the use of RES so far. The types of generators used in the thermal plant and their characteristics can be seen in the Table 1. The sum of output power of all generators is $0.940 \mathrm{MW}$ and the total production for the year 2017 according to HEDNO was 1012.66 MWh. The average annual variable fuel cost of conventional units is $250.02 € / \mathrm{MWh}$ for 2017 and the average annual additional operating and maintenance cost was estimated to $4.04 € / \mathrm{MWh}$. The total cost, which includes fuel cost, operating and maintenance cost, amortization of capital, interest payment and auxillary cost for the conventional system power plant was $662.71 € / \mathrm{MWh}$.

Table 1. Types of generators and their characteristics of Donoussa thermal plant provided by HEDNO [32].

\begin{tabular}{ccccc}
\hline No. & Type of Generator & Fuel & $\mathbf{P}_{\max }(\mathbf{M W})$ & $\mathbf{P}_{\min }(\mathbf{M W})$ \\
\hline 1 & MAN D2566ME & DIESEL & 0.080 & 0.045 \\
\hline 2 & MAN D2566ME & DIESEL & 0.080 & 0.045 \\
\hline 3 & MAN D2566ME & DIESEL & 0.080 & 0.045 \\
\hline 4 & VOLVO PENTA TAD 1345GE & DIESEL & 0.250 & 0.100 \\
\hline 5 & VOLVO PENTA TAD 1345GE & DIESEL & 0.250 & 0.100 \\
\hline 6 & VOLVO PENTA TAD 740GE & DIESEL & 0.200 & 0.110 \\
\hline
\end{tabular}




\subsection{Solar Irradiation Data and Wind Resource Assessment}

The daily radiation per month was imported in the HOMER software. Global horizontal irradiation data were retrieved from the Photovoltaic Geographical Information System for year 2016 for Donoussa island (latitude is 37.10656, longitude is 25.81385). The annual average solar global horizontal radiation is $5.42 \mathrm{kWh} / \mathrm{m}^{2} /$ day. The solar radiation data can be seen in Table 2. Figure 3 shows the Monthly Solar Radiation Sources and Clearness Index. Similar to solar resources, wind speeds at $50 \mathrm{~m}$ above ground level, from NASA Prediction of Worldwide Energy Resource (POWER), were imported into the HOMER software. Table 3 shows the average monthly wind speed of Donoussa. The average annual wind speed is $7.10 \mathrm{~m} / \mathrm{s}$. Inputs of monthly average wind speed in HOMER resulted in the comprehensive Figure 4.

Table 2. Donoussa monthly average solar radiation data.

\begin{tabular}{ccc}
\hline Month & Clearness Index & Daily Radiation $\mathbf{k W h} / \mathbf{m}^{2} /$ day \\
\hline January & 0.494 & 2.339 \\
\hline February & 0.617 & 3.759 \\
\hline March & 0.651 & 5.194 \\
\hline April & 0.726 & 7.133 \\
\hline May & 0.658 & 7.290 \\
\hline June & 0.732 & 8.467 \\
\hline July & 0.725 & 8.194 \\
\hline August & 0.717 & 7.355 \\
\hline September & 0.691 & 5.933 \\
\hline October & 0.642 & 4.258 \\
\hline November & 0.585 & 2.940 \\
\hline December & 0.506 & 2.181 \\
\hline
\end{tabular}

Table 3. Donoussa monthly average wind speed data.

\begin{tabular}{cc}
\hline Month & Average Wind Speed $(\mathbf{m} / \mathbf{s})$ \\
\hline January & 8.250 \\
\hline February & 7.080 \\
\hline March & 7.950 \\
\hline April & 5.200 \\
\hline May & 5.880 \\
\hline June & 5.560 \\
\hline July & 6.680 \\
\hline August & 8.250 \\
\hline September & 8.000 \\
\hline October & 6.380 \\
\hline November & 8.250 \\
\hline December & 7.720
\end{tabular}




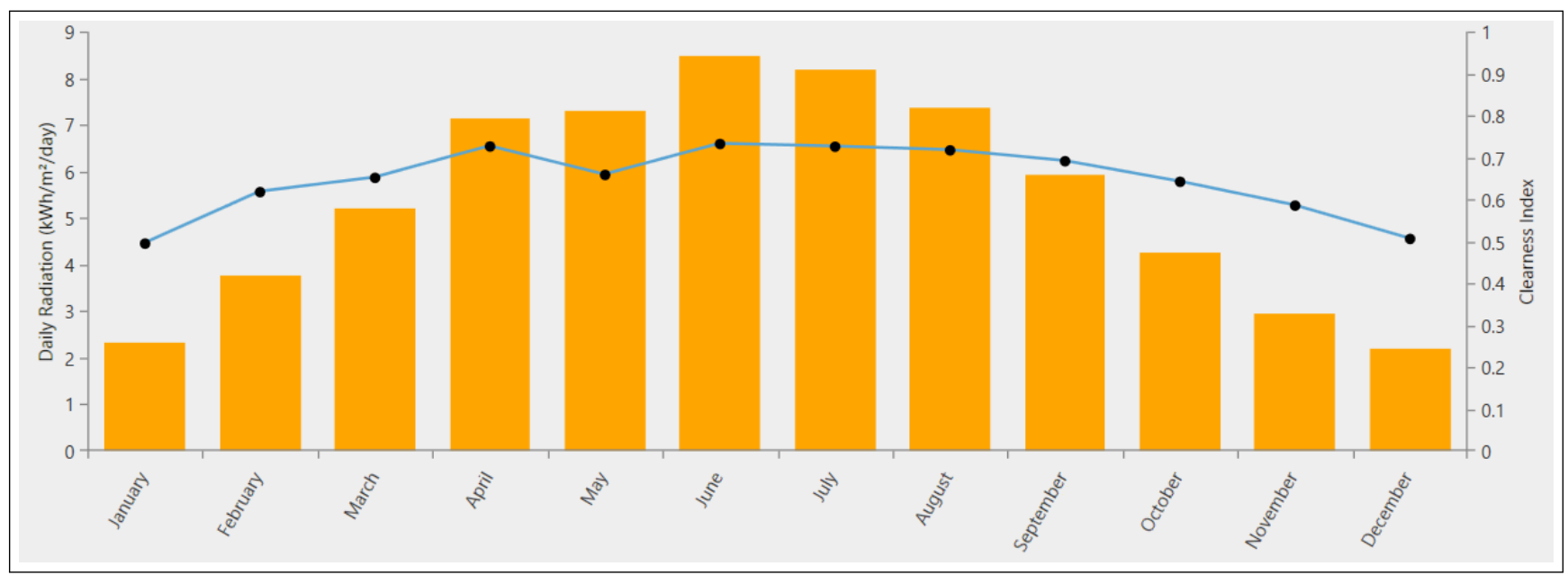

Figure 3. Monthly Solar Radiation Sources and Clearness Index.

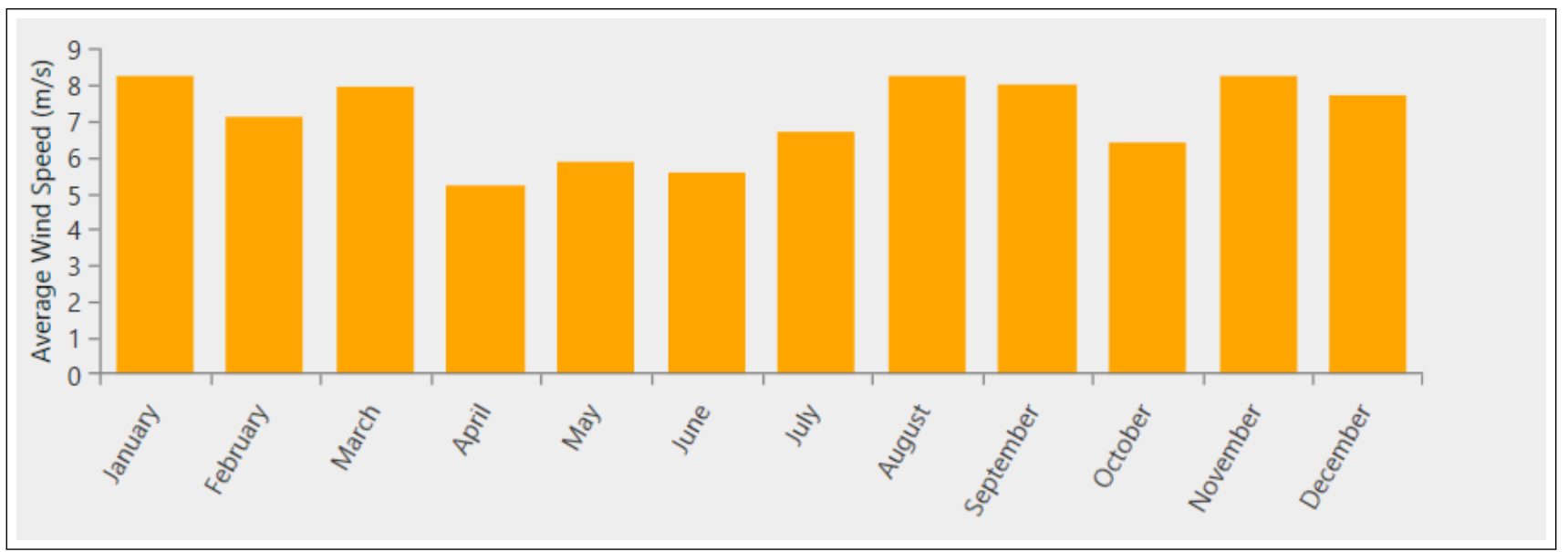

Figure 4. Average monthly wind speed of Donoussa island.

\subsection{Simulation Systems-Scenarios}

The power system of Donoussa island is composed of 6 diesel generators with total power of about $940 \mathrm{~kW}$ which is almost twice as large as the peak load of the system $(450 \mathrm{~kW})$. As a result the power system of Donoussa can be considered oversize. To that end, in this study 3 main scenarios were formulated for the electrification of the island of Donoussa.

- The first scenario includes Wind turbines, PV solar panels and five diesel generator units. The renewable fraction of this scenario is considered to be $20 \%$. In the Figure 5 below can be seen the configuration of this scenario.

- As for the second scenario the operation of three diesel generators are dismissed and only three diesel units $(200 \mathrm{~kW}, 250 \mathrm{~kW}$ and $80 \mathrm{~kW}$ respectively) operate along with wind turbine generators, PV solar panels and battery with a renewable fraction of $50 \%$. Figure 6 depicts the microgrid configuration of the second scenario.

- $\quad$ Finally, in the last scenario it was attempted the feasibility of the system only with RES production without the operation of conventional units. The hybrid system/microgrid consists of Wind turbines, PV solar panels and battery bank. As it is easily understood the renewable fraction of this scenario is $100 \%$. Moreover, two sub-cases are going to be considered. In the first sub-case autonomy days of battery are going to be assumed three and as for the second sub-case five days are assumed. The configuration is depicted in the Figure 7. 


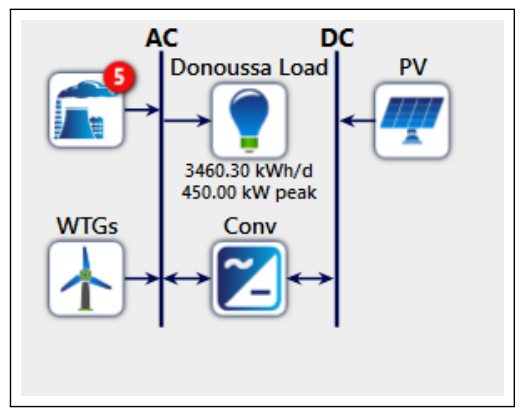

Figure 5. Scenario 1 Homer Pro Configuration.

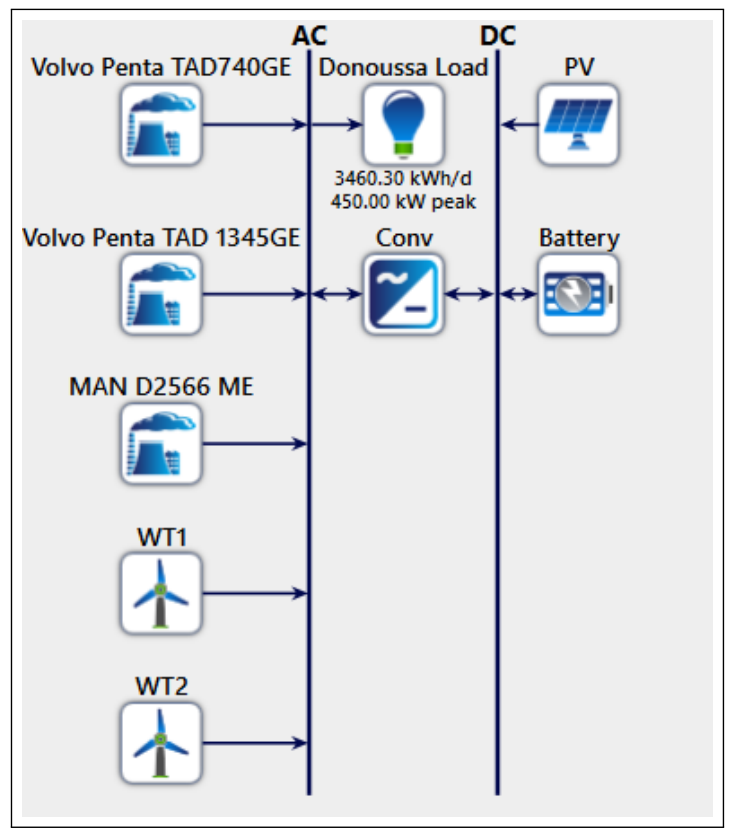

Figure 6. Scenario 2 Homer Pro Configuration.

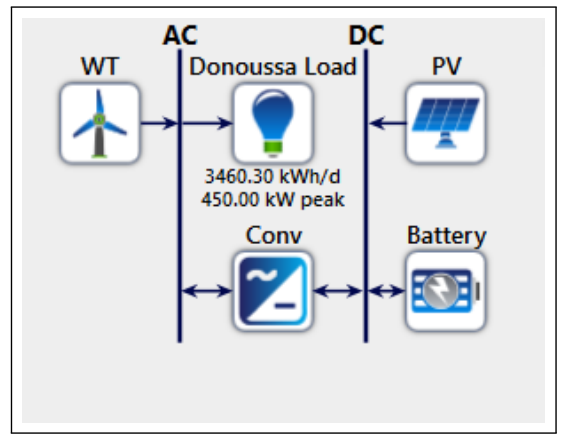

Figure 7. Scenario 3 Homer Pro Configuration.

\section{Modelling, Cost Data and Size Specification of Each Component of Hybrid System}

\subsection{Solar PV Analysis, Size and Cost}

PV array is modelled in HOMER software as a device that produces DC electricity using the global solar radiation in direct proportion. The output power of the the PV array is calculated by HOMER bu considering specific values as inputs. Slope, azimuth and ground reflectance are the most important ones and the derating factor of the effect of temperature is applied. Slope is defined as the angle at which the panels are placed relative to the horizontal plane. Typically in fixed-slope PV systems with slope equal to latitude the PV energy production is nearly maximized, in this case $37.10^{\circ}$. The azimuth is the direction that PV panels face. For south this is $0^{\circ}$, for north it is $180^{\circ}$, for east it is $-90^{\circ}$ and for west 
it is $90^{\circ}$. PV panels are oriented towards the equator with fixed-azimuth panels and the azimuth is $0^{\circ}$ in the northern hemisphere and $180^{\circ}$ in the southern hemisphere. Moreover, the fraction of solar radiation reflected on the ground is called ground reflectance. On tilted PV panels, this value is used for the calculation of the radiation incident. This value varies from $3 \%$ to $70 \%$ depended on the ground cover material and in this study is selected at $20 \%$ [19]. When the effect of temperature is taken into consideration HOMER software calculates the power output of PV panels according to the following formula.

$$
P_{p v}=W_{p v} \times f_{p v} \times \frac{G_{T}}{G_{S}} \times\left[1+\kappa_{p} \times\left(T_{C}-T_{S T C}\right)\right]
$$

where:

$W_{p v}=$ peak power output in $\mathrm{kW}$,

$f_{p v}=$ derating factor of $\mathrm{PV}(\%)$,

$G_{T}=$ solar radiation incident for a specific timeslot in $\mathrm{kW} / \mathrm{m}^{2}$,

$G_{s}=$ standard test conditions incident radiation number $\left(1 \mathrm{~kW} / \mathrm{m}^{2}\right)$,

$\kappa_{p}=$ temperature coefficient $(\% / C)$,

$T_{C}=$ instant $\mathrm{PV}$ module temperature $\left({ }^{\circ} \mathrm{C}\right)$,

$T_{S T C}=$ standard test conditions PV module temperature $\left(25^{\circ} \mathrm{C}\right)$.

The derating factor is selected at $80 \%$ and as a result the production of PV panels is set to $20 \%$ in order to model the real-world condition of dust and temperature. After surveying different studies focusing on the cost provided, for this study the Generic flat plate was chosen with a PV panel of $1 \mathrm{~kW}$. The cost of the PV panels varies in different studies and in different countries. The authors considered the capital cost of PV at $620 € / \mathrm{kW}$, same price also for the replacement cost. These costs include shipping, tariffs, installation, dealer mark-ups and insurances. Operation and maintenance cost are taken at $14 € /$ year. Lifetime of PV arrays is considered to be 25 years while tracking system is not included in the system of PV panels. The specifications for the chosen PV modules in the current study are highlighted in Table 4.

Table 4. PV technical speciifications and costs.

\begin{tabular}{cc}
\hline Parameters (Units) & Value \\
\hline Panel type & Flat plate \\
Derating factor $(\%)$ & $80 \%$ \\
Operating temperature $\left({ }^{\circ} \mathrm{C}\right)$ & $47^{\circ} \mathrm{C}$ \\
Temperature coefficient & -0.5 \\
Ground reflection $(\%)$ & $20 \%$ \\
Lifetime (years) & 25 years \\
Tracking system & No Tracking System \\
Capital Cost $(€)$ & $620 € / \mathrm{kW}$ \\
Replacement Cost $(€)$ & $620 € / \mathrm{kW}$ \\
Search Space Scenario 1 & $14 € /$ year \\
Search Space Scenario 2 & $40,50,60,70,80,90,100 \mathrm{~kW}$ \\
Search Space Scenario 3 Case 1 & $180,190,200,210,220,230,240,250,260 \mathrm{~kW}$ \\
Search Space Scenario 3 Case 2 & $1200,1250,1300,1350,1400,1450,1500,1550 \mathrm{~kW}$ \\
Operation & $1400,1450,1500,1550,1600,1650,1700,1750 \mathrm{~kW}$ \\
\hline
\end{tabular}




\subsection{Wind Turbine Modelling, Size and Cost}

Wind turbines are machines that extract energy from a steam of air in order to convert it into mechanical energy and then into electricity. The mechanical power captured by a wind turbine can be seen in the formula below $[25,29]$ :

$$
P=\frac{1}{2} \times C_{p} \times \rho \times A \times V^{3}
$$

where: $P=$ the mechanical power/kinetic power, $C_{p}$ is the power coefficient, $\rho$ is the air density, $A$ is the area swept by the wind, $V$ the speed of the wind. The choice for the optimal wind turbine for the hybrid system of this study depends on many factors. Depending on the wind speed sources, large wind turbines can be used in the hybrid system or a number of smaller wind turbines. In addition, the relatively low load demand of the island, the quantities of turbines, requiredservice time, hub height, the cost of the component, the type of electricity generated (AC/DC) and cut-in wind speed are some of the constraints on wind turbine choice. The wind turbines selected are the Eocycle EO20 and the Aeolos-H. Rated capacities are $20 \mathrm{~kW}, 10 \mathrm{~kW}$ respectively for Eocycle EO20 and $10 \mathrm{~kW}$ for Aeolos-H. According to different studies and market reports initial capital costs differ depending on the study, the capacity of the wind farm (turbine size) and region. The capital cost varies from $1500 € / \mathrm{kW}$ to $2250 € / \mathrm{kW}$. For this study the capital cost is set at $1800 € / \mathrm{kW}$ and the replacement cost is calculated almost at $80 \%$ of the initial capital cost. The operation and maintenance costs are assumed to be $3 \%$ of the initial capital cost. Tables 5 and 6 depict parametric inputs of wind turbine for HOMER software, some technical specifications and costs.

Table 5. Technical specifications and Costs of Eocycle EO20 Wind Turbine.

\begin{tabular}{cc}
\hline Parameters (Units) & Value \\
\hline Model & Eocycle EO20 \\
Nominal Capacity $(\mathrm{kW})$ & $20 \mathrm{~kW}$ \\
Rotor Diameter $(\mathrm{m})$ & $15.8 \mathrm{~m}$ \\
Cut-in/out wind speed $(\mathrm{m} / \mathrm{s})$ & $2.75 \mathrm{~m} / \mathrm{s}-20.00 \mathrm{~m} / \mathrm{s}$ \\
Hub/tower height $(\mathrm{m})$ & $36 \mathrm{~m}$ \\
Capital Cost $(€)$ & $35,800 €$ \\
Replacement Cost $(€)$ & $28,640 €$ \\
Scenario 1 Search Space & $1075 € /$ year \\
Scenario 2 Search Space & 1,2 units \\
\end{tabular}

Table 6. Technical specifications and Costs of Aeolos-H $10 \mathrm{~kW}$ Wind Turbine.

\begin{tabular}{cc}
\hline Parameters (Units) & Value \\
\hline Model & Aeolos-H 10 kW \\
Nominal Capacity $(\mathrm{kW})$ & $10 \mathrm{~kW}$ \\
Rotor Diameter $(\mathrm{m})$ & $8 \mathrm{~m}$ \\
Cut-in/out wind speed $(\mathrm{m} / \mathrm{s})$ & $3 \mathrm{~m} / \mathrm{s}-10.00 \mathrm{~m} / \mathrm{s}$ \\
Hub/tower height $(\mathrm{m})$ & $24 \mathrm{~m}$ \\
Capital Cost $(€)$ & $17,900 €$ \\
Replacement Cost $(€)$ & $14,320 €$ \\
Operation and Maintenance Cost $(€ /$ year $)$ & $540 € /$ year \\
Scenario 2 Search Space & 1,2 units \\
Scenario 3 Search Space Case 1 & $1,2,3,4,5,6,7$ units \\
Scenario 3 Search Space Case 2 & 1,2 units \\
\hline
\end{tabular}




\subsection{Batteries Modelling, Size and Cost}

In this study after examining different studies for off-grid hybrid systems and microgrids, lead-acid batteries are chosen due to low cost compared to Li-ion batteries. The model which is input through the HOMER tool library is the Hoppecke $24 \mathrm{OPzS} 3000$ from the manufacturer Hoppecke which is a lead-acid, deep-cycle type battery. Nominal capacity of this battery is $3570 \mathrm{Ah}(7.15 \mathrm{kWh})$ with a nominal voltage of 2 Volt. After surveying the market of batteries for the specific model, initial capital cost varies from $890 €$ to $1530 €$. Initial capital cost is considered $1200 €$, replacement cost for battery is assumed about $70 \%$ of its capital cost, that is $840 €$ and operation and maintenance, is $12 € /$ year/battery. In Table 7 can be seen the battery characteristics given by the manufacturer and the costs of the battery. In order to determine the optimal number of units for each scenario, a rough approximation is performed based on the methodology described below. According to the following formula the total required capacity of the battery bank (Ah) is calculated [3]:

$$
C_{\text {tot,cap }}=\frac{n_{\text {day }} \times E_{L}}{\eta_{b a t} \times D O D \times V_{b a t}}
$$

where:

$C_{\text {tot,cap }}=$ total required capacity of the battery bank (Ah),

$n_{\text {day }}=$ number of autonomy days of the system secured by the storage device,

$E_{L}=$ average daily energy consumption $(\mathrm{kWh})$,

$\eta_{\text {bat }}=$ overall battery and inverter efficiency,

$D O D=$ Depth of Discharge of the battery $(\%)$,

$V_{\text {bat }}=$ battery nominal voltage (2 Volt).

$E_{L}$ is $3460.3 \mathrm{kWh}$ for this study. Overall battery and inverter efficiency is calculated at 0.82 , Depth of Discharge of the battery (DOD) is 0.7 and the number of autonomy days of the battery is selected for Scenario $2 n_{\text {day }}=1$ and for Scenario 3 (Wind-PV-Battery) $n_{\text {day }}=3$ and $n_{\text {day }}=5$. So $C_{t o t, c a p}$ for Scenario 2 is calculated at $3014.2 \mathrm{Ah}$ and for Scenario 3 at 9042.6 Ah and $15071 \mathrm{Ah}$ respectively. After that the total number of batteries is calculated using the equation.

$$
n_{\text {batteries }}=\frac{C_{\text {tot }, \text { cap }}}{C_{\text {single }}}
$$

where: $n_{\text {batteries }}$ is the number of the required batteries, $C_{\text {single }}$ is the capacity of a single battery $(7.15 \mathrm{kWh})$ for this study. As a result of the above, the number of batteries for Scenario 2 is estimated at 422 batteries and for Scenario 3 at 1264 or 2108 batteries, depending on the days for autonomy. The DC bus voltage is considered at 24 Volt. The nominal system voltage of the DC bus (48 Volt) should be equal to the overall voltage produced by the total number of strings of the battery. The number of strings are calculated according to the next formula. The voltage of a single bus as mentioned earlier is 2 Volts, so each string is going to contain 12 batteries $(12 \times 2 \mathrm{~V}=24)$,

$$
n_{\text {string }}=\frac{n_{\text {batteries }}}{V_{D C b u s} / V_{b a t}}
$$

where:

$n_{\text {string }}=$ number of strings of the battery,

$n_{\text {batteries }}=$ number of the required batteries,

$V_{D C b u s}=\mathrm{DC}$ bus voltage,

$V_{b a t}=$ battery nominal voltage (2 Volts).

According to Formula (5), for Scenario 1 the number of strings is equal to 35.16, approximated to integer 35 strings corresponding to 420 batteries. In addition, as for Scenario 3 with autonomy days, $n_{\text {day }}=3$, the number of batteries was 1264 . Using Equation (5) the number of strings is calculated at 105.33 approximated to 105 strings and the number 
of batteries decreases at 1260 . For the second sub-case with autonomy days, $n_{\text {day }}=5$ the calculated number of batteries was 2108 and number of strings according to Formula (5) is 175.66 , approximated to integer 176 strings corresponding to 2112 batteries.

Table 7. Technical specifications and costs of Hoppecke 24 OPzS 3000 battery.

\begin{tabular}{cc}
\hline Parameters (Units) & Value \\
\hline Nominal Voltage $(\mathrm{V})$ & $2 \mathrm{~V}$ \\
Nominal Capacity $(\mathrm{kWh})$ & $7.15 \mathrm{kWh}$ \\
Maximum Capacity $(\mathrm{Ah})$ & $3570 \mathrm{Ah}$ \\
Round efficiency $(\%)$ & $86 \%$ \\
Minimum State of Charge $(\%)$ & $30 \%$ \\
Maximum Charge Current $(\mathrm{A})$ & $610 \mathrm{~A}$ \\
Lifetime (years) & 20 years \\
Capital Cost $(€)$ & $1200 €$ \\
Replacement Cost $(€)$ & $840 €$ \\
Operating and Maintenance Cost $(€ /$ year $)$ & $12 € /$ year \\
\hline
\end{tabular}

\subsection{Converter Size and Cost}

A converter is an essential part of the hybrid system in order to maintain the balance of energy between AC and DC. A converter can operate as both an inverter and a rectifier. In this study the efficiency of the inverter and the rectifier is set at $90 \%$ and $85 \%$, respectively, while the lifetime is set at 15 years. The initial capital cost of converter according to [1], is $250 € / \mathrm{kW}$ and operational and maintenance cost is $230 € / \mathrm{kW}$. Converter sizes considered in this study are: Scenario 1: 80, 90, 100 and $200 \mathrm{~kW}$, Scenario 2: 100, 200, 300, 400 and $500 \mathrm{~kW}$ and Scenario 3: Case 1 400, 410, 420, 430, 440, 450, 460, 470, 480, 490 and $500 \mathrm{~kW}$ and Case 2 200, 250, 300, 350, 400, 450, 500, 550 and $600 \mathrm{~kW}$.

\subsection{Economic Inputs}

\subsubsection{Net Present Cost (NPC)}

HOMER software calculates the NPC of each proposed power system and ranks them in descending order based on NPC. The NPC of a system is the present value of all costs during its life minus revenues and present value of the system. It is an important indicator as it shows if the whole investment is profitable or not. The NPC is given by the formula below [9]:

$$
N P C=\frac{C_{a n n, t o t}}{C R F\left(i, R_{\text {proj }}\right)}
$$

where:

$C_{a n n, t o t}=$ total annualized cost $(\$ /$ year $)$,

$C R F=$ capital recovery factor (calculated in Formula (7)),

$i=$ real discount rate,

$R_{\text {proj }}=$ project lifetime.

The real discount rate was considered at $4.25 \%$ and the inflation rate at $0 \%$ according to the Bank of Greece [33], so the expected real discount rate calculated from Formula (7) is $4.25 \%$ and it is used for the calculation of the NPC cost. In addition, project lifetime is set at 25 years and all the costs are measured in the currency of Euro. The capital recovery factor (CRF) is a formula which is used for the calculation of the present value of an annuity. The equation of CRF can be seen below.

$$
\operatorname{CRF}(i, N)=\frac{i \times(1+i)^{N}}{(1+i)^{N}-1}
$$

where $N$ is the number of years, $i$ is the real discount rate. 


\subsubsection{Levelized Cost of Energy (LCoE)}

Levelized cost of Energy (LCoE or COE) is defined by HOMER as the average (cost $/ \mathrm{kWh}$ ) of useful electrical energy produced by the system. This quantity is calculated from the following equation.

$$
\text { COE }=\frac{C_{\text {ann,tot }}-c_{\text {boiler }} \times H_{\text {served }}}{E_{\text {served }}}
$$

where:

$C_{a n n, t o t}=$ total annualized cost $(\$ /$ year $)$,

$c_{\text {boiler }}=$ boiler marginal cost $(\$ / \mathrm{kWh})$,

$H_{\text {served }}=$ total thermal load served $(\mathrm{kWh} /$ year $)$,

$E_{\text {served }}=$ total electrical load served $(\mathrm{kWh} /$ year $)$.

$E_{\text {served }}$ is calculated by adding AC primary load served ( $\mathrm{kWh} /$ year) $\left(E_{p r, A C}\right), \mathrm{DC}$ primary load served $\left(\mathrm{kWh}\right.$ /year) $\left(E_{p r, D C}\right)$ and total grid sales $(\mathrm{kWh} /$ year $)\left(E_{g r, s a l e s}\right)$. In this study, no energy sale to the grid is considered [34].

\subsection{Excess Electricity Assessment}

Excess Electricity is surplus energy that is produced in a hybrid system. This energy cannot be directed to neither load demand nor the batteries and therefore it must be dumped or curtailed. It is usually produced by the intermittent nature of RES when battery is not able to store the Excess Electricity because it is fully charged or by a generator when its minimum output exceeds the load. Excess Electricity is an important parameter for the voltage and frequency stability of the system and must be zero in order for the system to operate in a stable manner and supply electricity reliably to consumers. Excess power can be usable in many ways. Desalination systems like Reverse Osmosis especially on islands can use the excess power for their operation. Besides, Excess Electricity can be reused for the cooling and the heating of households. The surplus energy that the system is not able to use, might be dispersed in a dump load, typically a simple resistive heater or a bank of light bulbs.

\section{Results and Discussion}

In this chapter we discussed the optimization results for each scenario. The assessment covers both the technical and economical system performance for 20 years lifetime. Optimization results are studied in respect with the lowest Excess Electricity Energy which is a factor that can cause a lot of stability problems and is the main parameter guiding the selection of the optimal system for each scenario. Then the optimal hybrid system is selected with respect to the lowest NPC and LCoE.

\subsection{Optimization Results for Scenario 1/Diesel-PV-Wind Hybrid system}

The optimization results can be seen in the Table 8 for Scenario 1 . The most optimal Hybrid Renewable Energy System to meet the load demand of Donoussa island for this scenario, consists of: $100 \mathrm{~kW} \mathrm{PV,} 2$ Eocycle Wind Turbines, 5 operating conventional units (diesel generators) and 1 converter of $80 \mathrm{~kW}$. The Excess Electricity percentage is very low at $6.68 \%(90,807 \mathrm{kWh} /$ year) and the RES participate in the production as a percentage $20.2 \%$ over the RF limit. The dispatch strategy that is used is Cycle Charging, with NPC at $4,950,408 €$ and LCoE at $0.2948 €$. The total power production of this power system setup is 1,359,120 kWh/year. Excess electricity, present in the scenario we studied, does not necessarily indicate inadequacies in system design. On the contrary, sometimes including components that produce more electricity than is required is more economical for the system, rather than to invest on excess electricity storage infrastructure. Moreover, excess electricity can be reused for heating and cooling load for households as well as in desalination systems. The detailed production of each component and their technical characteristics can be seen in Table 9. Some useful remarks regarding Scenario 1 can be 
derived from Table 9. The load demand on the island is satisfied with 5 out of 6 diesel generators of the existing power systems. The main production to cover the needs of the island in this scenario comes from diesel generators which are already installed on the island. Conventional units produce nearly $74.18 \%$ of the total production. The low operational hours of Diesel generators (TAD 1345GE $855 \mathrm{~h}$ /year) suggest that the system could cope with fewer conventional units (Scenario 2). In this specific scenario RES produce $20.2 \%$ of the total production of electricity for the island load demand. The monthly electrical production of each component can be seen in Figure 8. The diesel generator Volvo Penta TAD1345GE seems to operate many hours during the summer months when load demand is high due to tourism. The total fuel consumed is 249,215 diesel L/year with heavy fuel emissions.

Table 8. Scenario 1 Optimization results.

\begin{tabular}{|c|c|c|c|c|c|c|c|c|c|c|c|c|c|}
\hline 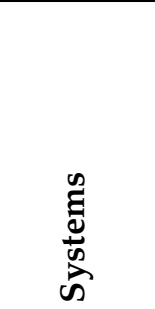 & $\begin{array}{l}\hat{z} \\
z \\
z\end{array}$ & $\begin{array}{l}\mathbb{E} \\
3 \\
\text { oิ } \\
0 \\
0\end{array}$ & 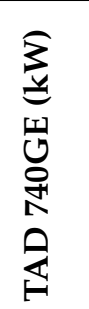 & 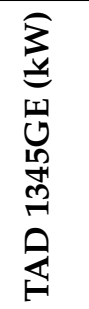 & 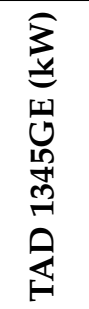 & 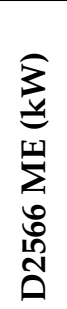 & 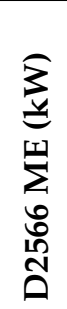 & 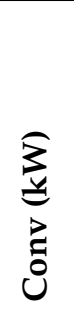 & 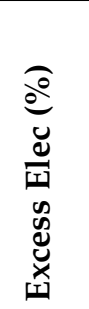 & 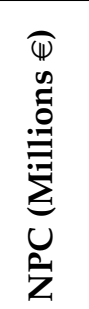 & $\begin{array}{l}\mathbb{\Psi} \\
0 \\
0\end{array}$ & 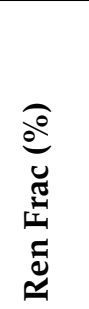 & 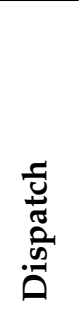 \\
\hline System 1 & 100 & 2 & 200 & 250 & 250 & 80 & 80 & 80 & 6.68 & 4.95 & 0.295 & 20.2 & $\mathrm{CC}$ \\
\hline
\end{tabular}

Figure 9 and Table 10 depict the output power and the electricity simulation results of solar PV. Electricity generation is maximized in January, February and November. The rated capacity of PV panels on this scenario is $100 \mathrm{~kW}$ with a maximum power output of $88.6 \mathrm{~kW}$. The total hours of operation of solar PV panels is $4386 \mathrm{~h} /$ year and it can be easily deduced that PV panels work almost 12 hours per day. As far as Wind Turbines are concerned, power output by the Wind Turbines is depicted in Figure 10. It is high throughout the year with a maximum of $40.6 \mathrm{~kW}$ in February. Furthermore, wind penetration is at a low percentage $14.7 \%$ due to the 2 wind turbines are used in this scenario. Table 11 shows the Wind Turbines scheme simulation results.

Table 9. Analytical Electrical Production and technical characteristics for optimal configuration of Scenario 1.

\begin{tabular}{|c|c|c|c|c|c|}
\hline System Components & Production (kWh/year) & Production \% & Mean Output (kW) & Annual Fuel Consumption L/year & Operational Hours h/year \\
\hline PV & 164,853 & 12.1 & 18.8 & - & 4386 \\
\hline TAD740GE & 151,860 & 11.2 & 112 & 36,447 & 1353 \\
\hline TAD 1345GE & 509,656 & 37.5 & 150 & 119,781 & 3396 \\
\hline TAD 1345GE & 9486 & 0.698 & 112 & 2,229 & 85 \\
\hline MAN D2566 ME & 234,188 & 17.2 & 45 & 27,737 & 2291 \\
\hline MAN D2566 ME & 103,095 & 7.59 & 47.1 & 63,022 & 4976 \\
\hline Eocycle EO20 & 185,982 & 13.7 & 21.2 & - & 7708 \\
\hline Total & $1,359,120$ & 100 & - & 249,215 & - \\
\hline
\end{tabular}

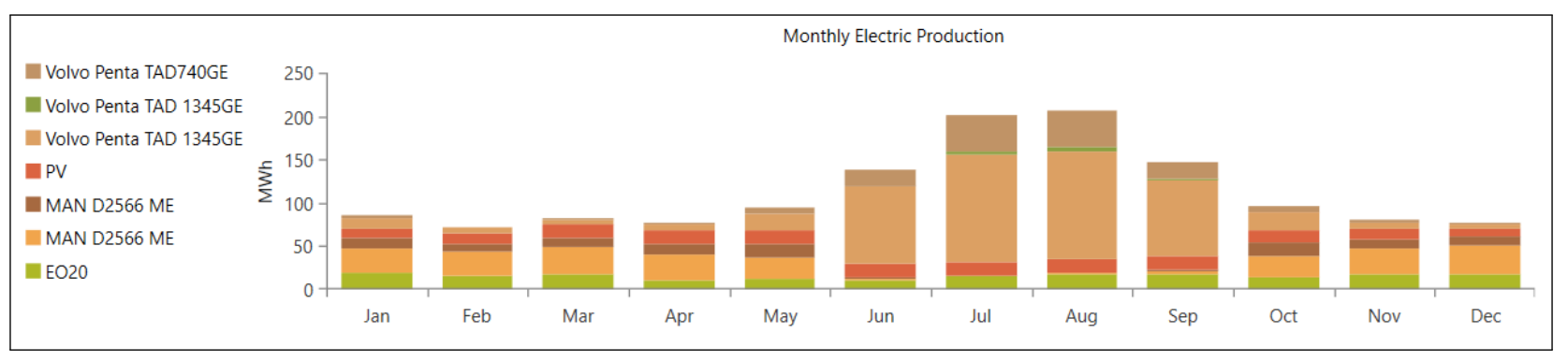

Figure 8. Monthly Electrical Production of Scenario 1. 


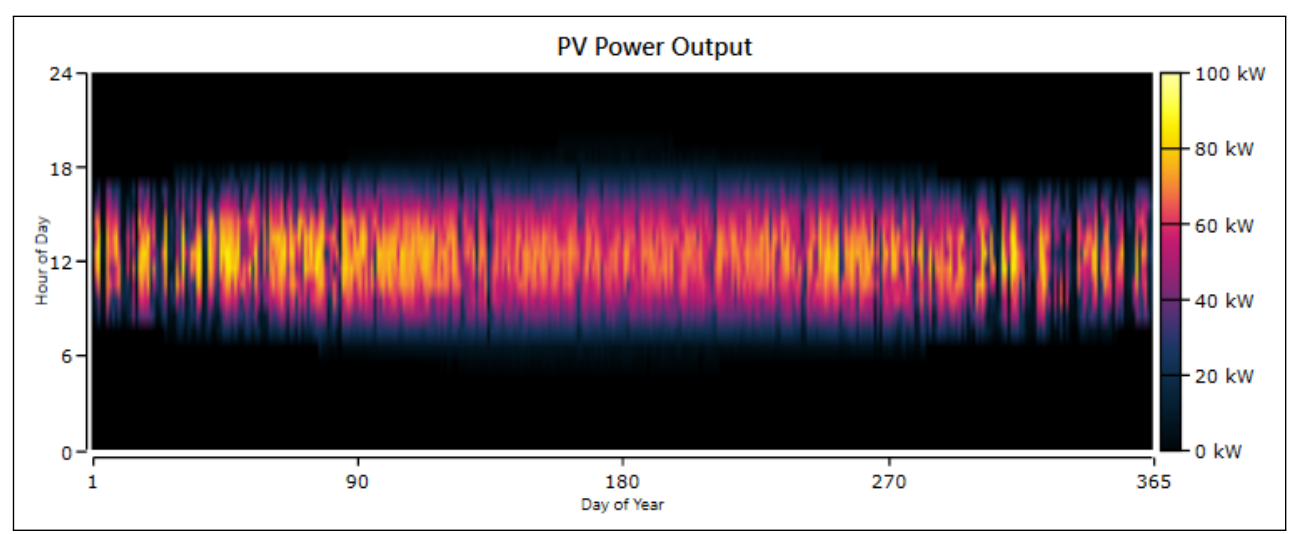

Figure 9. PV Power output.

Table 10. PV Scheme Simulation Results.

\begin{tabular}{ccc}
\hline Quantity & Value & Units \\
\hline Rated capacity & 100 & $\mathrm{~kW}$ \\
\hline Minimum Output & 0 & $\mathrm{~kW}$ \\
\hline Maximum Output & 88.6 & $\mathrm{~kW}$ \\
\hline Mean Output & 18.8 & $\mathrm{~kW}$ \\
\hline Mean Output & 452 & $\mathrm{kWh} / \mathrm{d}$ \\
\hline Capacity Factor & 18.8 & $\%$ \\
\hline Total Production & 164,853 & $\mathrm{kWh} /$ year \\
\hline PV Penetration & 13.1 & $\%$ \\
\hline Hours of Operation & 4386 & $\mathrm{~h} / \mathrm{year}$ \\
\hline Levelized Cost & 0.0343 & $€ / \mathrm{kWh}$ \\
\hline
\end{tabular}

Table 11. Wind Turbines Scheme Simulation Results.

\begin{tabular}{ccc}
\hline Quantity & Value & Units \\
\hline Rated capacity & 20 & $\mathrm{~kW}$ \\
\hline Minimum Output & 0 & $\mathrm{~kW}$ \\
\hline Maximum Output & 40.6 & $\mathrm{~kW}$ \\
\hline Mean Output & 21.2 & $\mathrm{~kW}$ \\
\hline Capacity Factor & 53.1 & $\%$ \\
\hline Total Production & 185,982 & $\mathrm{kWh} /$ year \\
\hline Wind Penetration & 14.7 & $\%$ \\
\hline Hours of Operation & 7708 & $\mathrm{hrs} /$ year \\
\hline Levelized Cost & 0.0405 & $€ / \mathrm{kWh}$ \\
\hline & &
\end{tabular}

Regarding the system costs, the optimal configuration was selected according to the minimum NPC cost and LCoE. The main economic aspects for the optimal system are presented in Table 12. It can be easily seen that the main cost of the selected configuration is the fuel costs with a value of 4,595,337.32 $€$. This can be justified from the fact that diesel generators operate in order to satisfy the load demand and the fuel consumption happens at very high rate. The Initial cost/Capital cost is very low since diesel generator units have been already installed in power system of Donoussa. Cash flow during the lifetime 
of the project is depicted in Figure 11. In addition, the main source of costs comes from diesel generators and more specifically from VOLVO PENTA TAD1345GE with total cost of 2,305,670.09€ and then the rest diesel generators follow. On the other hand, the RES (Wind Turbines and PV panels) have a little share of the total NPC of the hybrid system. Detailed costs by each component are depicted in the Table 13.

According to HEDNO the power station of Donoussa island produced 1012.66 MWh in 2017. In addition, the average annual variable cost of conventional units of the Donoussa power system for the year 2017 is equal to $250.02 € / \mathrm{MWh}$. The total annual cost can be easily calculated at $253,185.25 €$ and if it is considered an average yearly cost, for lifetime of 20 years the total cost of the existing power system of Donoussa is 5,063,705.06 €. The total NPC of Scenario 1 is 4,950,407.61 $€$ which is a lower value from the cost for the existing power system by $113,297.45 €$. This observation makes the optimal configuration of Scenario 1 feasible and economical viable for Donoussa island.

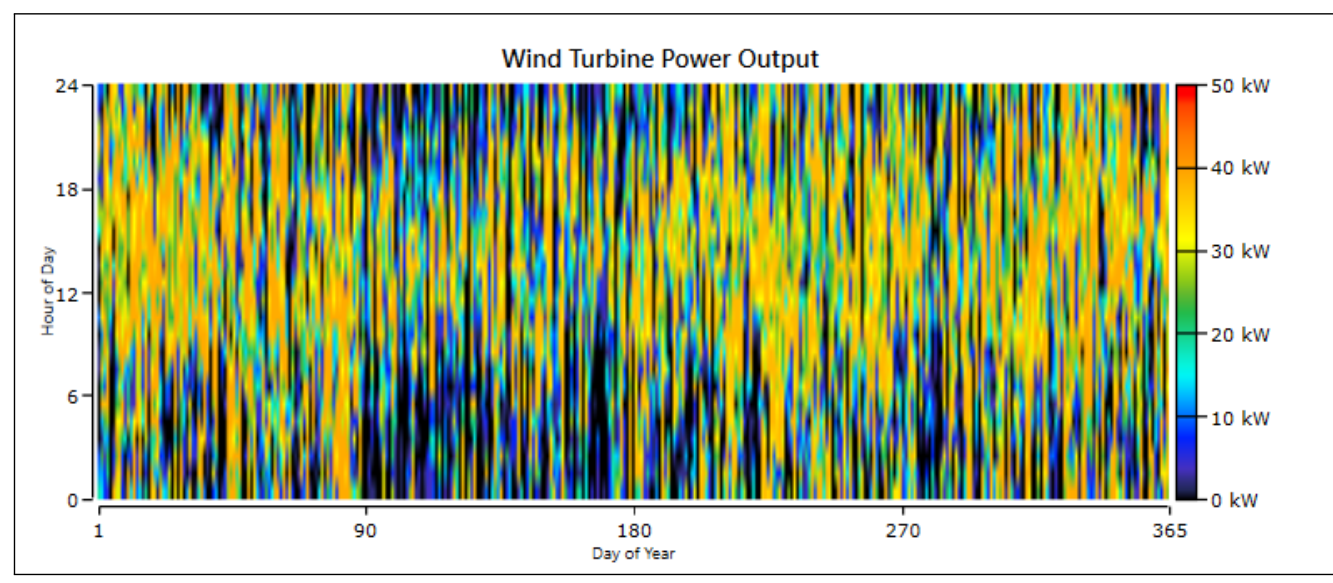

Figure 10. Wind Turbine Power output.

Table 12. Economic characteristics of the optimal configuration of Scenario 1.

\begin{tabular}{cccccccc}
\hline System & NPC $(€)$ & LCoE $(€)$ & Capital $(€)$ & Replacement $(€)$ & Salvage $(€)$ & O \& M ( $€ /$ year) & Fuel (€) \\
\hline Optimal & $4,950,407.61$ & 0.2948 & 153,600 & $175,581.04$ & $-36,535.63$ & $62,424.89$ & $4,595,337.32$ \\
\hline
\end{tabular}

Table 13. Analytical costs of each component Scenario 1.

\begin{tabular}{ccccccc}
\hline Component & Capital $(€)$ & Replacement $(€)$ & $\mathbf{O} \& \mathbf{M}(€)$ & Fuel $(€)$ & Salvage $(€)$ & Total $(€)$ \\
\hline Eocycle E020 & 71,600 & 0.00 & $28,556.30$ & 0.00 & 0.00 & $100,156.30$ \\
\hline Generic Flat plate PV & 62,000 & 0.00 & $18,612.11$ & 0.00 & -5393.87 & $75,218.24$ \\
\hline $\begin{array}{c}\text { Generic large, free } \\
\text { converter }\end{array}$ & 20,000 & 9855.46 & 0.00 & 0.00 & -5335.87 & $24,519.59$ \\
\hline MAN D2566 ME & 0.00 & $36,378.24$ & 3969.17 & $1,162,073.04$ & -125.28 & $1,202,295.17$ \\
\hline MAN D2566 ME & 0.00 & $15,555.28$ & 1827.44 & $511,442.71$ & -1090.95 & $527,734.48$ \\
\hline $\begin{array}{c}\text { VOLVO PENTA } \\
\text { TAD1345GE }\end{array}$ & 0.00 & $98,032.64$ & 6772.15 & $2,208,667.27$ & -7801.97 & $2,305,670.09$ \\
\hline $\begin{array}{c}\text { VOLVO PENTA } \\
\text { TAD1345GE }\end{array}$ & 0.00 & 0.00 & 169.50 & $41,106.68$ & $-14,656.24$ & $26,619.94$ \\
\hline $\begin{array}{c}\text { VOLVO PENTA } \\
\text { TAD1740GE }\end{array}$ & 0.00 & $15,759.42$ & 2518.22 & $672,047.62$ & -2131.45 & $688,193.81$ \\
\hline System & 153,600 & $175,581.04$ & $62,424.89$ & $4,595,337.32$ & $-36,535.63$ & $4,950,407.61$ \\
\hline
\end{tabular}




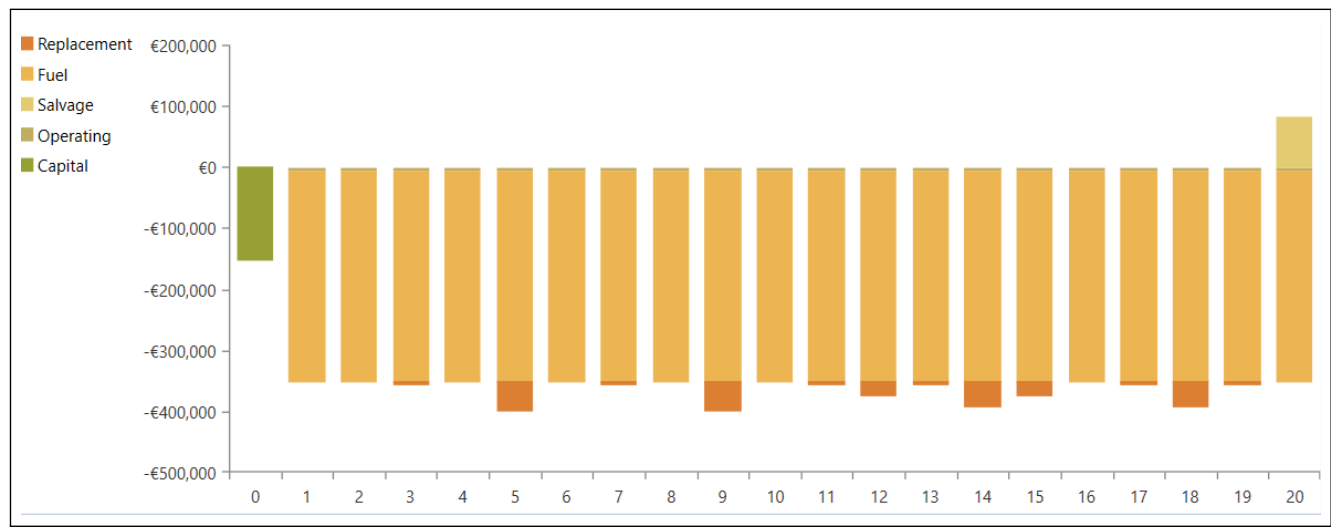

Figure 11. Cash flow by Cost type Scenario 1.

\subsection{Optimization Results for Scenario 2/Diesel-PV-Wind-Battery Hybrid System}

In Scenario 2 the hybrid system is composed of Wind Turbines, PV panels, battery storage and diesel generators. Renewable fraction for this case is at $50 \%$, after the optimization, the configuration shown in Table 14 is the optimal system. The main target of this Scenario is the reduction of Excess Electricity as well as the NPC, the LCoE and the number of conventional units. Optimal feasible system has Excess Electricity at a $\%$ rate. The optimal hybrid system consists of $260 \mathrm{~kW}$ of Panels, 2 Wind Turbines of type Eocycle EO20 (20 kW), 2 Aeolos-H (10 kW) Wind Turbines, 1 unit of VOLVO PENTA TAD740GE diesel generator, 1 unit of VOLVO PENTA TAD1345GE diesel generator, 1 unit of MAN D2566ME diesel generator, 420 battery units and a converter of $200 \mathrm{~kW}$. Where the diesel generators provided just enough power to serve the load without charging the batteries a load following (LF) dispatch strategy is selected. The NPC is at 4,031,102 € and LCoE at $0.2401 €$. Table 15 presents the technical and electrical characteristics of the optimal system. The total power production of this power system setup is 1,307,797 kWh/year. The excess electricity in the current scenario, which can be used in auxiliary services, is also a result of the system design in order to minimize the cost of the components used in the proposed infrastructure. Regarding Table 15 some important remarks can be drawn concerning the optimal configuration of Scenario 2. Comparing to Scenario 1 and with the existing power system of Donoussa island, the hybrid system includes only 3 diesel generator units instead of 5 in system of Scenario 1. The production is divided almost equally between the conventional units and the RES with almost $47.28 \%$ of the total production coming from diesel generators and almost $52.7 \%$ from RES. The low operational hours of the diesel generator VOLVO PENTA TAD1345GE indicates that with a possible increase in RES the hybrid system could meet the load demand with fewer operational conventional units. The monthly electrical production of each component is presented in Figure 12.

Table 14. Scenario 2 Optimization results.

\begin{tabular}{|c|c|c|c|c|c|c|c|c|c|c|c|c|c|}
\hline 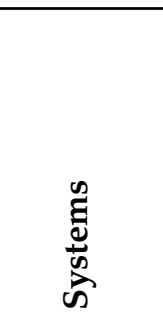 & $\begin{array}{l}\underset{z}{y} \\
z \\
z\end{array}$ & 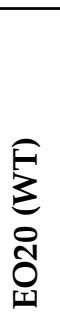 & $\frac{T}{\frac{1}{8}}$ & 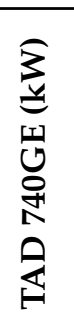 & 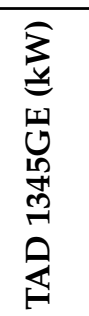 & 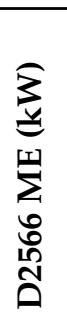 & 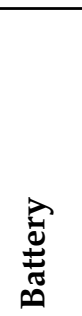 & $\begin{array}{l}\underset{z}{z} \\
z \\
\tilde{j}\end{array}$ & 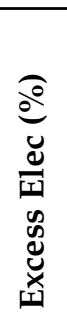 & 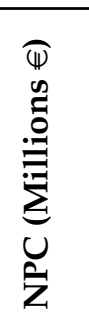 & $\begin{array}{l}\mathbb{\Psi} \\
\underline{\tilde{y}} \\
0\end{array}$ & 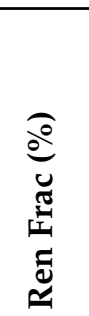 & 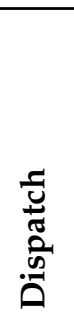 \\
\hline System 1 & 260 & 2 & 2 & 200 & 250 & 80 & 420 & 200 & 0 & 4.03 & 0.240 & 51.0 & LF \\
\hline
\end{tabular}


Table 15. Analytical electrical Production and technical characteristics for optimal configuration of Scenario 2.

\begin{tabular}{cccccc}
\hline System Components & Production (kWh/year) & Production $\%$ & Mean Output (kW) & Annual Fuel Consumption (L/year) & Operational Hours (h/year) \\
\hline PV & 428,618 & 32.8 & 48.9 & - & 4386 \\
\hline TAD740GE & 429,150 & 32.8 & 136 & 109,093 & 3153 \\
\hline TAD 1345GE & 60,600 & 4.63 & 111 & 17,332 & 548 \\
\hline MAN D2566 ME & 128,867 & 9.85 & 47.7 & 34,682 & - \\
\hline Eocycle EO20 & 185,982 & 14.2 & 21.2 & - & 7708 \\
\hline Aeolos-H (10 kW) & 74,579 & 5.70 & 8.51 & 161,106 & - \\
\hline Total & $1,307,797$ & 100 & - & & - \\
\hline
\end{tabular}

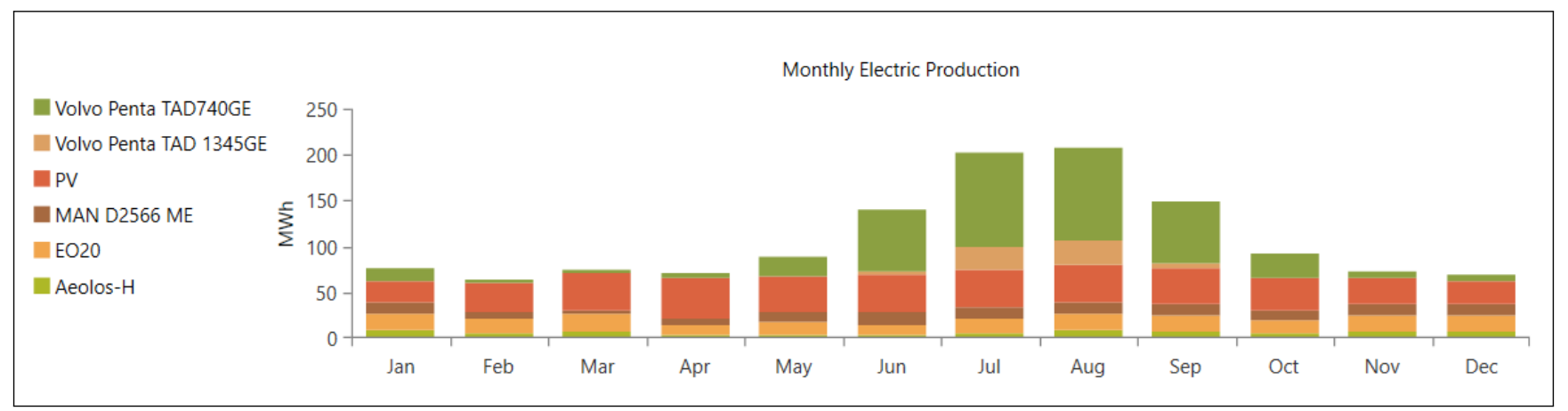

Figure 12. Monthly electrical production of each component of Scenario 2.

The greatest share in electrical production has the generator VOLVO PENTA TAD740GE with $429,150 \mathrm{kWH} /$ year and $32.8 \%$ in total production. The maximum power output of VOLVO PENTA TAD740GE occurs during the summer months, that is June-August, due to tourism. On the other hand, the power output is significantly reduced for the rest of the year. As for the other two conventional units of the optimal configuration, as mentioned earlier VOLVO PENTA TAD1345GE operate few hours during the year with a mean electrical output of $111 \mathrm{~kW}$. MAN D2566ME with mean output at $47.7 \mathrm{~kW}$ operates $2703 \mathrm{~h} /$ year with a stable rate. In addition, the total fuel consumed is 161,106 diesel $\mathrm{L} /$ year which is considered a much lower value than fuel consumption in Scenario $1(249,215 \mathrm{~L} /$ year $)$ due to the reduction of conventional units.

Solar PV panels have a great share in the total electrical production of this Scenario with $32.8 \%$. PV have a rated capacity in the optimal system configuration of $260 \mathrm{~kW}$ and a mean output of $48.9 \mathrm{~kW}$. There is a clear increase on the rated capacity of PV panels compared to Scenario 1 due to the increase in the Renewable Fraction from $20 \%$ to $50 \%$. In Figure 13 and in Table 16 can be observed PV scheme simulation results. As far as Wind Turbines are concerned, the optimal configuration hybrid system includes 4 Wind Turbines, a combination of 2 Eocycle EO20 $(20 \mathrm{~kW})$ and 2 of Aeolos-H $(10 \mathrm{~kW})$ with a total sum of $60 \mathrm{~kW}$. In this scenario wind energy contributes in electrical production with almost $20 \%$ in total electrical production. Wind turbines operate under their mean output only a few months during the year. Wind Turbine scheme simulation results and power output are depicted in Figure 14 and in Tables 17 and 18. Figure 14 highlights the high reliance on wind energy. In this scenario there is an extra important parameter for the hybrid system which is the energy storage. Batteries were solely charged by the RES based on the Load Following dispatch strategy. From Figure 15 one can derive that battery is at low levels of charge during spring and summer months due to the fact that battery has to contribute to energy production to meet the load demand. Battery is at high levels of charge mainly during the winter months due to the high operation of RES. Battery scheme simulation results are presented in Table 19.

The NPC for the optimal system configuration is at 4,031,102.03€ and LCoE is $0.2401 €$. There is a sufficient difference between NPC of Scenario 1 and Scenario 2. Table 20 summarizes the financial aspects of the optimal configuration of Scenario 2 . It can be 
easily derived that the main type of costs are fuel costs with $2,970,686.19 €$. Fuel costs are almost at half price of fuel costs of Scenario 1. Capital costs are 822,600.00€ and have the second greatest share in total costs of the hybrid system. Capital costs are justified from the purchase, transportation and installation of RES, which have larger rated capacity than in Scenario 1. Cash flow during the lifetime of the project is presented in Figure 16. The analytical costs for each component for the optimal configuration are highlighted in Table 21. High share in the total cost have firstly the two of three conventional units and then battery. The existence of battery in the selected hybrid system increases the cost, in contrast PV panels and Wind Turbines have not such great share in the total cost of the system. Furthermore, replacement costs of Scenario 2 are 112,901.73 $€$ less than Scenario 1 $(175,581.04 €)$ where 4 out of 5 conventional units are included in the replacement costs. The total NPC cost of the optimal configuration of the current Scenario is more economically viable than cost of Scenario 1 and calculated cost of existing power system. Scenario 2 is considered the most economical feasible with a $\% \%$ of Excess Electricity. For the period of twenty years, almost one million Euros is saved by this hybrid system configuration while the load is fully satisfied.

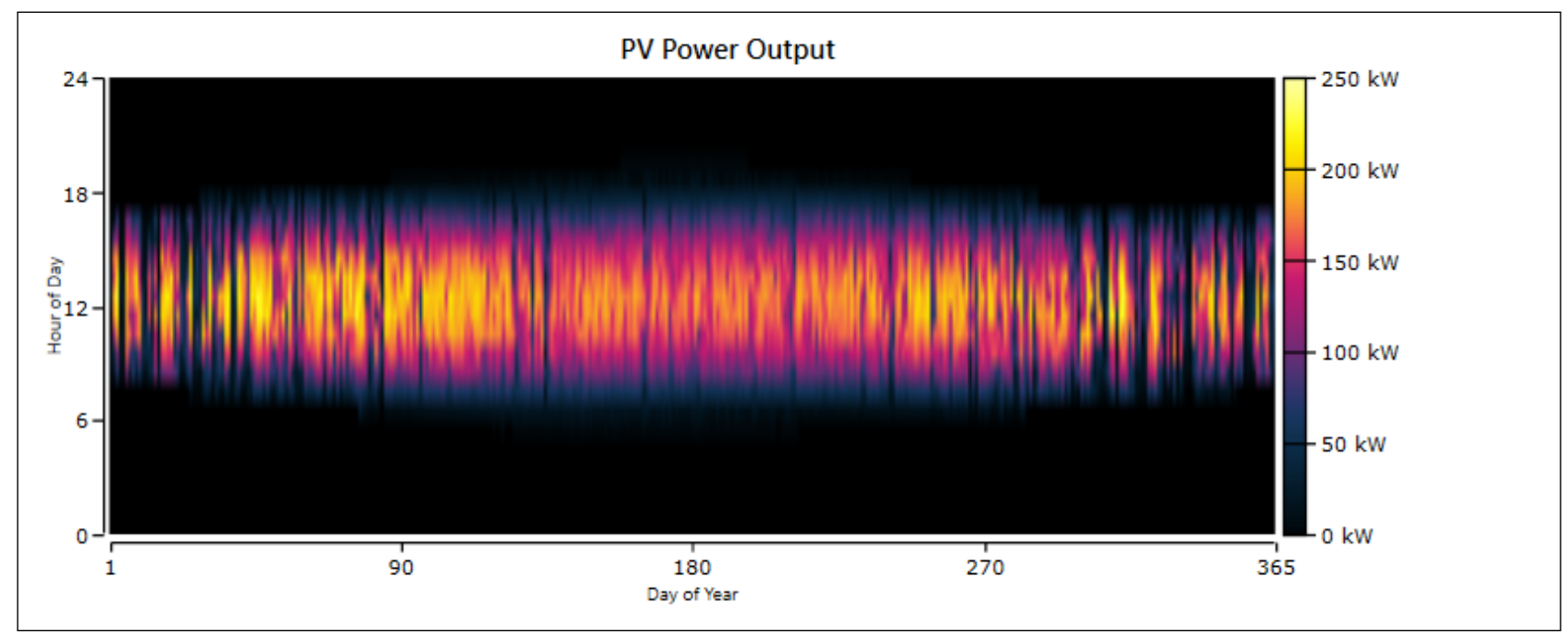

Figure 13. PV power output Scenario 2.

Table 16. PV Scheme Simulation Results.

\begin{tabular}{ccc}
\hline Quantity & Value & Units \\
\hline Rated capacity & 260 & $\mathrm{~kW}$ \\
\hline Minimum Output & 0 & $\mathrm{~kW}$ \\
\hline Maximum Output & 230 & $\mathrm{~kW}$ \\
\hline Mean Output & 48.9 & $\mathrm{~kW}$ \\
\hline Mean Output & 1174 & $\mathrm{kWh} / \mathrm{d}$ \\
\hline Capacity Factor & 18.8 & $\%$ \\
\hline Total Production & 428,618 & $\mathrm{kWh} /$ year \\
\hline PV Penetration & 33.9 & $\%$ \\
\hline Hours of Operation & 4386 & $\mathrm{~h} /$ year \\
\hline Levelized Cost & 0.0343 & $€ / \mathrm{kWh}$ \\
\hline
\end{tabular}


Table 17. Eocycle EO20 (20 kW) Scheme Simulation Results.

\begin{tabular}{ccc}
\hline Quantity & Value & Units \\
\hline Rated capacity & 40 & $\mathrm{~kW}$ \\
\hline Minimum Output & 0 & $\mathrm{~kW}$ \\
\hline Maximum Output & 40.6 & $\mathrm{~kW}$ \\
\hline Mean Output & 21.2 & $\mathrm{~kW}$ \\
\hline Capacity Factor & 53.1 & $\mathrm{kWh} / \mathrm{year}$ \\
\hline Total Production & 185,982 & $\%$ \\
\hline Wind Penetration & 14.7 & $\mathrm{~h} /$ year \\
\hline Hours of Operation & 7708 & $€ / \mathrm{kWh}$ \\
\hline Levelized Cost & 0.0405 &
\end{tabular}

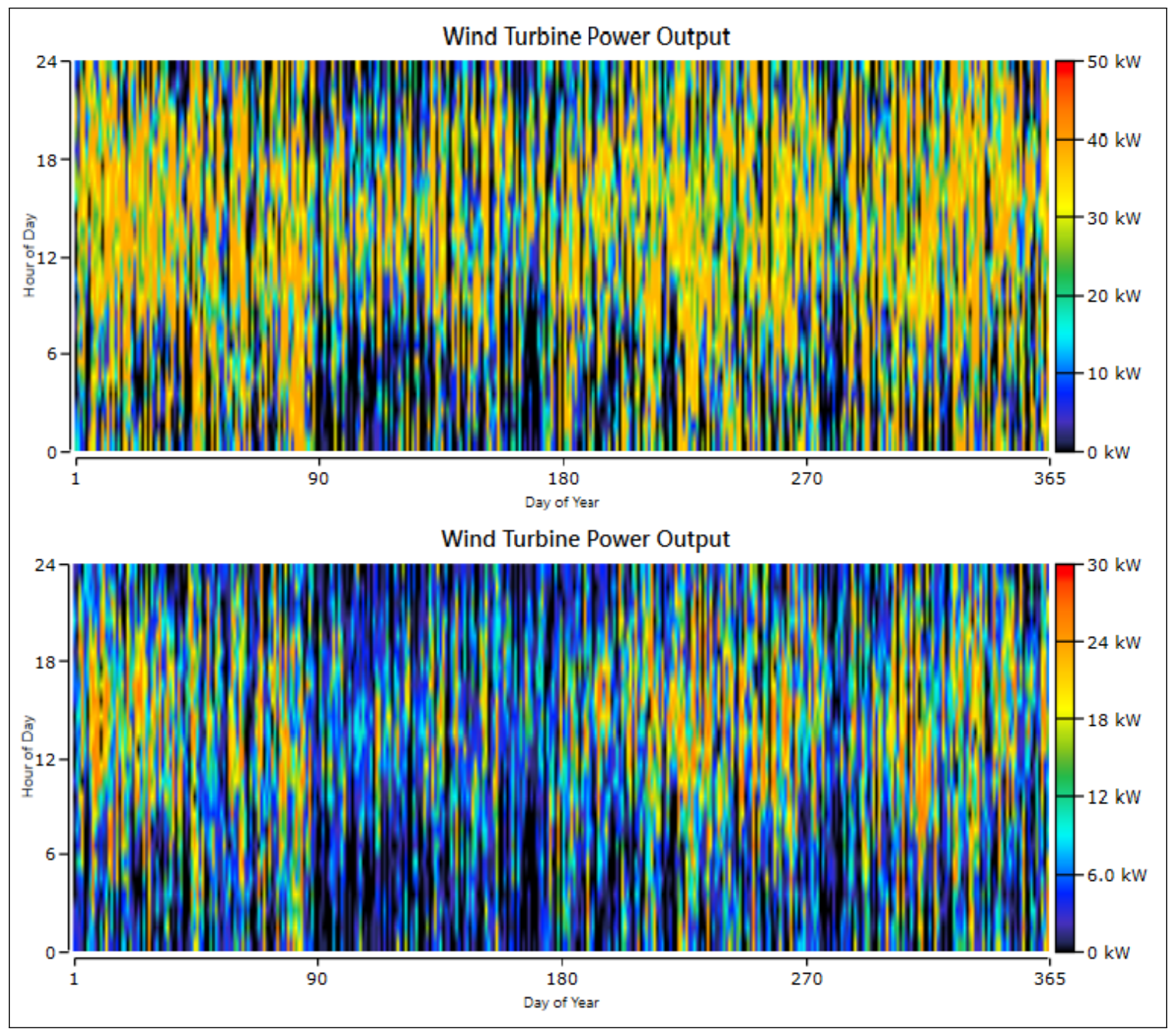

Figure 14. Eocycle EO20 (20 kW) (upper figure) and Aeolos-H (10 kW) (down figure) power output Scenario 2. 
Table 18. Aeolos-H (10 kW) Scheme Simulation Results.

\begin{tabular}{ccc}
\hline Quantity & Value & Units \\
\hline Rated capacity & 20 & $\mathrm{~kW}$ \\
\hline Minimum Output & 0 & $\mathrm{~kW}$ \\
\hline Maximum Output & 27.6 & $\mathrm{~kW}$ \\
\hline Mean Output & 8.51 & $\mathrm{~kW}$ \\
\hline Capacity Factor & 42.6 & $\%$ \\
\hline Total Production & 74,579 & $\mathrm{kWh} /$ year \\
\hline Wind Penetration & 5.9 & $\%$ \\
\hline Hours of Operation & 7374 & $\mathrm{~h} /$ year \\
\hline Levelized Cost & 0.0506 & $€ / \mathrm{kWh}$ \\
\hline
\end{tabular}

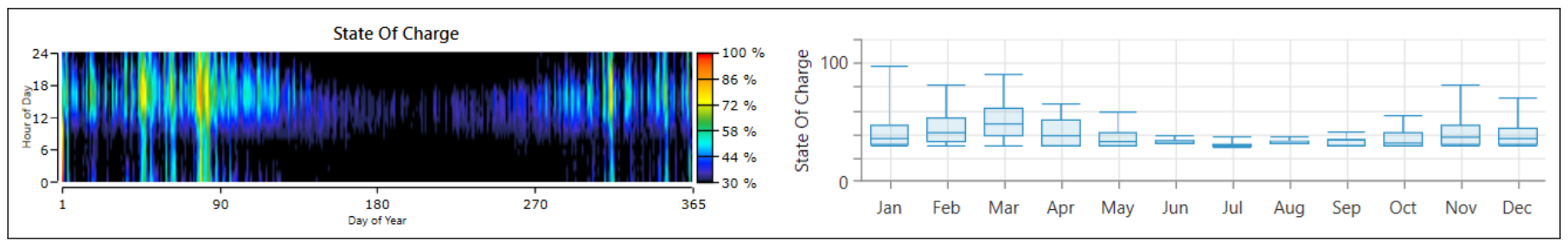

Figure 15. Battery State-of-Charge Scenario 2.

Table 19. Battery Scheme Simulation Results.

\begin{tabular}{ccc}
\hline Quantity & Value & Units \\
\hline Batteries & 420 & qty \\
\hline String Size & 12.0 & batteries \\
\hline Strings in Parallel & 35.0 & strings \\
\hline Bus Voltage & 24.0 & $\mathrm{~V}$ \\
\hline Autonomy & 14.6 & $\mathrm{hr}$ \\
\hline Storage Wear Cost & 0.0895 & $€ / \mathrm{kWh}$ \\
\hline Nominal Capacity & 3003 & $\mathrm{kWh}$ \\
\hline Usable Nominal Capacity & 2102 & $\mathrm{kWh}$ \\
\hline Energy In & 162,376 & $\mathrm{kWh} /$ year \\
\hline Energy Out & 141,538 & $\mathrm{kWh} /$ year \\
\hline Storage Depletion & 2043 & $\mathrm{kWh} /$ year \\
\hline Losses & 22,881 & $\mathrm{kWh} /$ year \\
\hline Annual Throughput & 152,625 & $\mathrm{kWh} /$ year \\
\hline
\end{tabular}

Table 20. Economic characteristics of the optimal configuration of Scenario 2.

\begin{tabular}{lccccccc}
\hline System & NPC $(€)$ & LCoE $(€)$ & Capital $(€)$ & Replacement $(€)$ & Salvage $(€)$ & O \& M $(€ /$ year) & Fuel $(€)$ \\
\hline Optimal & $4,031,102$ & 0.2401 & 822,600 & $112,901.73$ & $-42,539.07$ & $167,453.17$ & $2,970,686.19$ \\
\hline
\end{tabular}




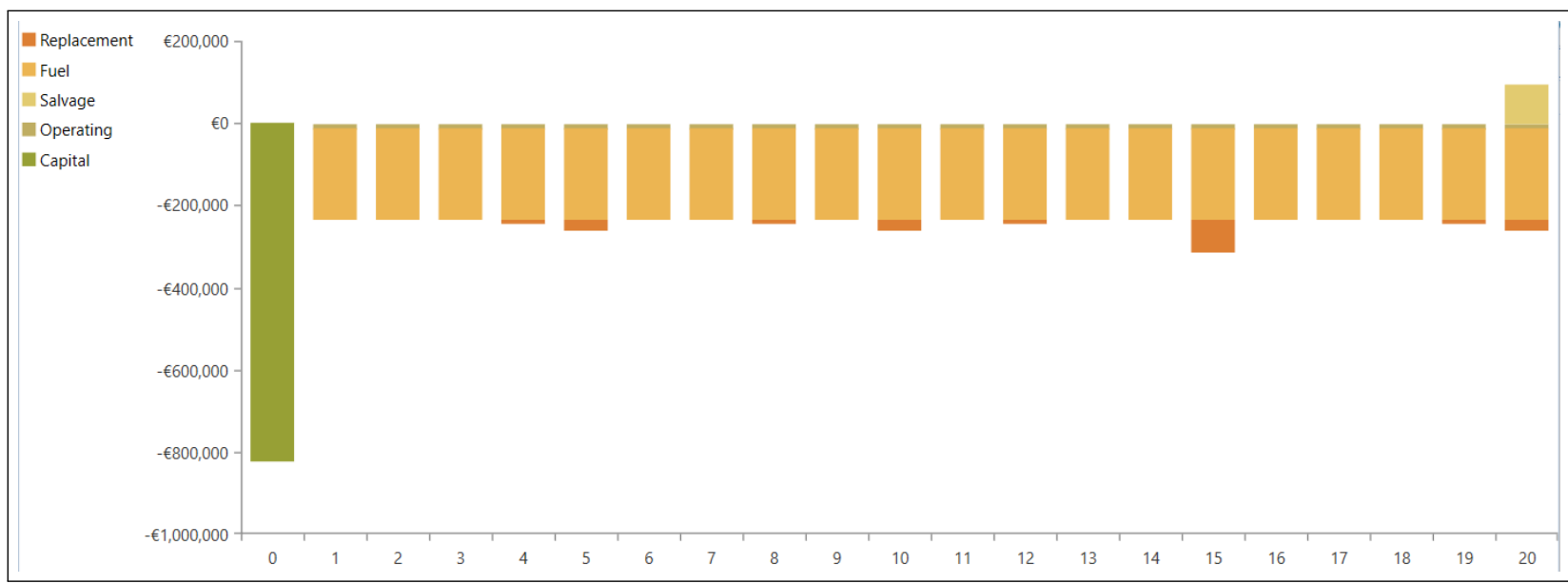

Figure 16. Cash flow by Cost Type Scenario 2.

Table 21. Analytical costs of each component Scenario 2.

\begin{tabular}{ccccccc}
\hline Component & Capital $(€)$ & Replacement $(€)$ & O \& M (€) & Fuel $(€)$ & Salvage $(€)$ & Total $(€)$ \\
\hline Aeolos-H 10 kW & $35,800.00$ & 0.00 & $14,357.92$ & 0.00 & 0.00 & $50,157.92$ \\
\hline Eocycle EO20 & $71,600.00$ & 0.00 & $25,582.89$ & 0.00 & 0.00 & $100,182.89$ \\
\hline Generic Flat plate PV & $161,200.00$ & 0.00 & $48,391.49$ & 0.00 & $-14,024.06$ & $195,567.43$ \\
\hline Generic large, free converter & $50,000.00$ & $24,638.65$ & 0.00 & 0.00 & $-13,339.68$ & $61,298.97$ \\
\hline Hoppecke 24OPzS 3000 & $504,000.00$ & 0.00 & $67,003.60$ & 0.00 & 0.00 & $571,003.60$ \\
\hline MAN D2566 ME & 0.00 & $25,803.75$ & 2156.08 & $639,502.17$ & -2067.07 & $665,394.93$ \\
\hline VOLVO PENTA TAD1345GE & 0.00 & $98,032.64$ & 6772.15 & $2,208,667.27$ & -7801.97 & $2,305,670.09$ \\
\hline VOLVO PENTA TAD1345GE & 0.00 & 0.00 & $1,092.80$ & $319,589.11$ & -4451.97 & $316,229.93$ \\
\hline VOLVO PENTA TAD740GE & 0.00 & $62,459.33$ & 5868.40 & $2,011,594.91$ & -8656.29 & $2,071,266.35$ \\
\hline System & $822,600.00$ & $112,901.73$ & $167,453.17$ & $2,970,686.19$ & $-42,539.07$ & $4,031,102.03$ \\
\hline
\end{tabular}

\subsection{Optimization Results for Scenario 3/Wind-PV-Battery}

Scenario 3 is composed of a $100 \%$ RES. As was observed by Scenarios 1 and 2, is possible for the system to meet the island's load demand with the least number of conventional units. In this scenario all diesel generators were removed from the simulations in order for $100 \%$ renewable hybrid system to be examined. An 100\% renewable, off-grid system could face electricity supply problems and the uncertainty of the time and the amount of the power delivered to customers. In the current scenario, two cases are going to be examined: one case with 1260 batteries and one with 2112 batteries. For the first case the optimal system includes $1450 \mathrm{~kW}$ of PV panels, 7 Wind Turbines (Aeolos-H $10 \mathrm{~kW}$ ), 1260 Battery units, a $470 \mathrm{~kW}$ converter and a Cycle Charging dispatch strategy (CC). The optimal system for the second case of Scenario 3, consists of $1450 \mathrm{~kW}$ of PV panels, 2 Wind Turbines (Aeolos-H $10 \mathrm{~kW}$ ), 2112 battery units, a $450 \mathrm{~kW}$ converter with a Load Following (LF) dispatch strategy. The NPC is at 3,759,814.85€ and the LCoE at $0.2241 €$ for case 1 and for case 2 NPC is 5,217,030.15€ and LCoE is $0.3107 €$. However, the two systems face the problem of the unmet electrical load and the capacity shortage at a very small percentage $0.0818 \%$ and $0.0997 \%$ of Unmet Electric Load and Capacity Shortage for case 1 and $0.00810 \%$ and $0.0224 \%$ for case 2 . In both cases, percentage-wise, those numbers are low, almost zero and are considered easily manageable. As for Excess Electricity percentage, touches almost half of the energy output with $46.8 \%$ for case 1 while is at $41.8 \%$ for case 2 . The total power production of this power system setup is 1,359,120 kWh/year. Like in the previous scenarios, in this scenario the excess electricity is scheduled by system design as a result of reducing the total investment cost of the infrostructure over the spanned period. 
Tables 22 and 23 present the technical and electrical characteristics of the optimal system for case 1 and case 2 of Scenario 3.

Table 22. Analytical Electrical Production and technical characteristics for optimal configuration of Scenario 3 case 1.

\begin{tabular}{|c|c|c|c|c|c|}
\hline \multirow{2}{*}{ System Components } & \multirow{2}{*}{ Size } & \multicolumn{2}{|c|}{ Electricity Production } & \multirow{2}{*}{ Mean Output (kW) } & \multirow{2}{*}{ Operational Hours (h/year) } \\
\hline & & kWh/year & $\%$ & & \\
\hline PV & $1450 \mathrm{~kW}$ & $2,390,365$ & 90.2 & 273 & 4386 \\
\hline Aeolos-H (10 kW) & $7(70$ kW) & 261,025 & 9.84 & 29.8 & 7374 \\
\hline Total & 1520 & $2,651,391$ & 100 & - & - \\
\hline Battery Hoppecke & $\begin{array}{c}1260 \\
(9009 \mathrm{kWh})\end{array}$ & $\begin{array}{c}\text { Energy in } \\
678,208 \mathrm{kWh} / \text { year }\end{array}$ & $\begin{array}{c}\text { Energy out } \\
583,614 \mathrm{kWh} / \text { year }\end{array}$ & $\begin{array}{l}\text { Annual throughput } \\
629,327 \mathrm{kWh} / \text { year }\end{array}$ & Autonomy $43.7 \mathrm{~h}$ \\
\hline
\end{tabular}

Table 23. Analytical Electrical Production and technical characteristics for optimal configuration of Scenario 3 case 2.

\begin{tabular}{|c|c|c|c|c|c|}
\hline \multirow{2}{*}{ System Components } & \multirow{2}{*}{ Size } & \multicolumn{2}{|c|}{ Electricity Production } & \multirow{2}{*}{ Mean Output (kW) } & \multirow{2}{*}{ Operational Hours (h/year) } \\
\hline & & kWh/year & $\%$ & & \\
\hline PV & $1450 \mathrm{~kW}$ & $2,390,365$ & 97 & 273 & 4386 \\
\hline Aeolos-H $(10 \mathrm{~kW})$ & $2(20 \mathrm{~kW})$ & 74,579 & 3.03 & 8.51 & 7374 \\
\hline Total & 1,470 & $2,464,944$ & 100 & - & - \\
\hline Battery Hoppecke & $\begin{array}{c}2112 \\
(15,099 \mathrm{kWh})\end{array}$ & $\begin{array}{c}\text { Energy in } \\
783,923 \mathrm{kWh} / \text { year }\end{array}$ & $\begin{array}{c}\text { Energy out } \\
674,837 \mathrm{kWh} / \text { year }\end{array}$ & $\begin{array}{l}\text { Annual throughput } \\
727,696 \mathrm{kWh} / \text { year }\end{array}$ & Autonomy $73.3 \mathrm{~h}$ \\
\hline
\end{tabular}

From Tables 22 and 23 some useful remarks can be derived. In two optimal configurations for the two cases of Scenario 3 it is easily noticed that PV panels have a greater share of energy production. In both cases rated capacity of PV panels is the same. PV panels in both cases are the main source of the supply of electricity in a stable way to Donoussa island because their production is more predictable. Monthly electrical production of each component is depicted in Figure 17 for both cases. PV power output and PV scheme simulation results are highlighted in Figure 18 and Table 24 for both cases. Wind Turbines have a more "auxiliary" role in the Scenario 3 in both cases among with the battery units. This fact can be confirmed from the contribution of them in the electrical production with $9.84 \%$ for Case 1 and $3.03 \%$ for Case 2. January, March and July are the months that the maximum power output of Wind Turbine appears. Aeolos-H power output for Case 1 and Case 2 is presented in Figure 19. Tables 25 and 26 depict the Wind Turbine Scheme simulation results for the two cases of Scenario 3.

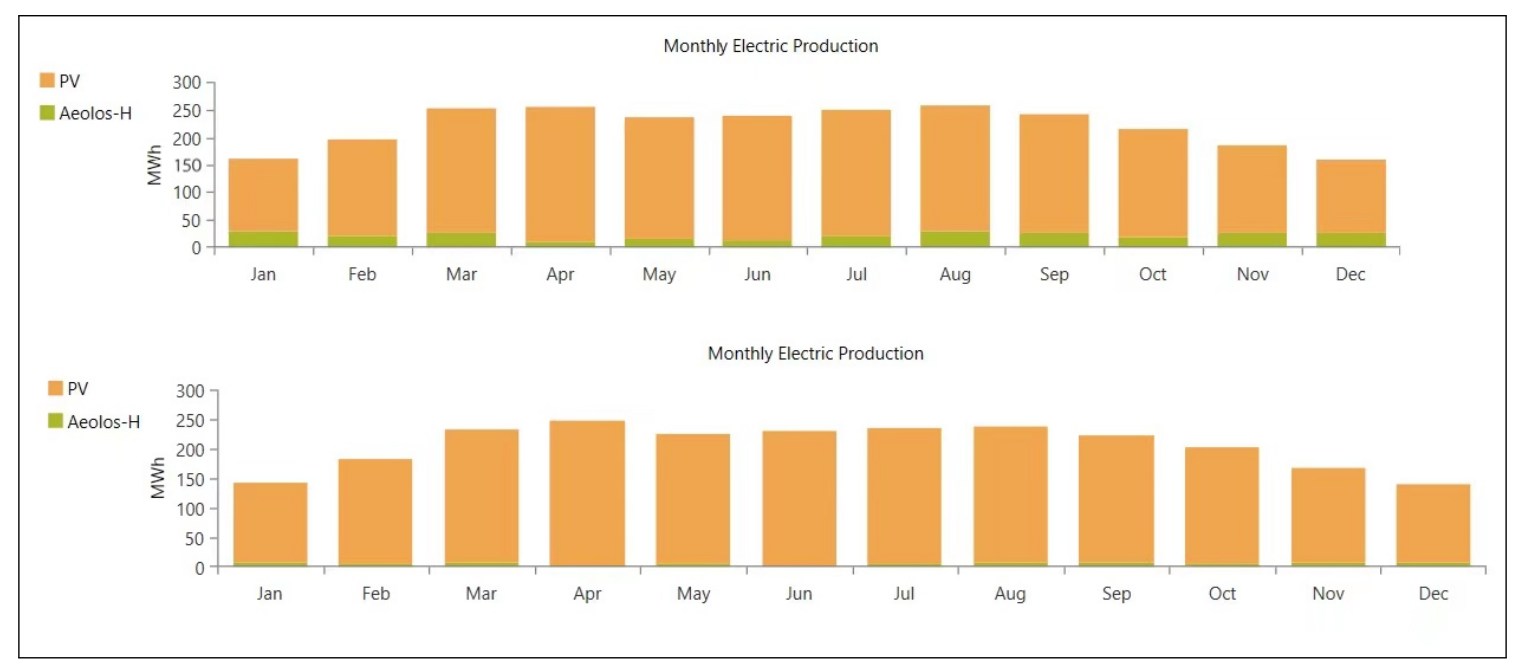

Figure 17. Monthly electrical Production Case 1 (upper figure) and Case 2 (bottom figure) Scenario 3. 


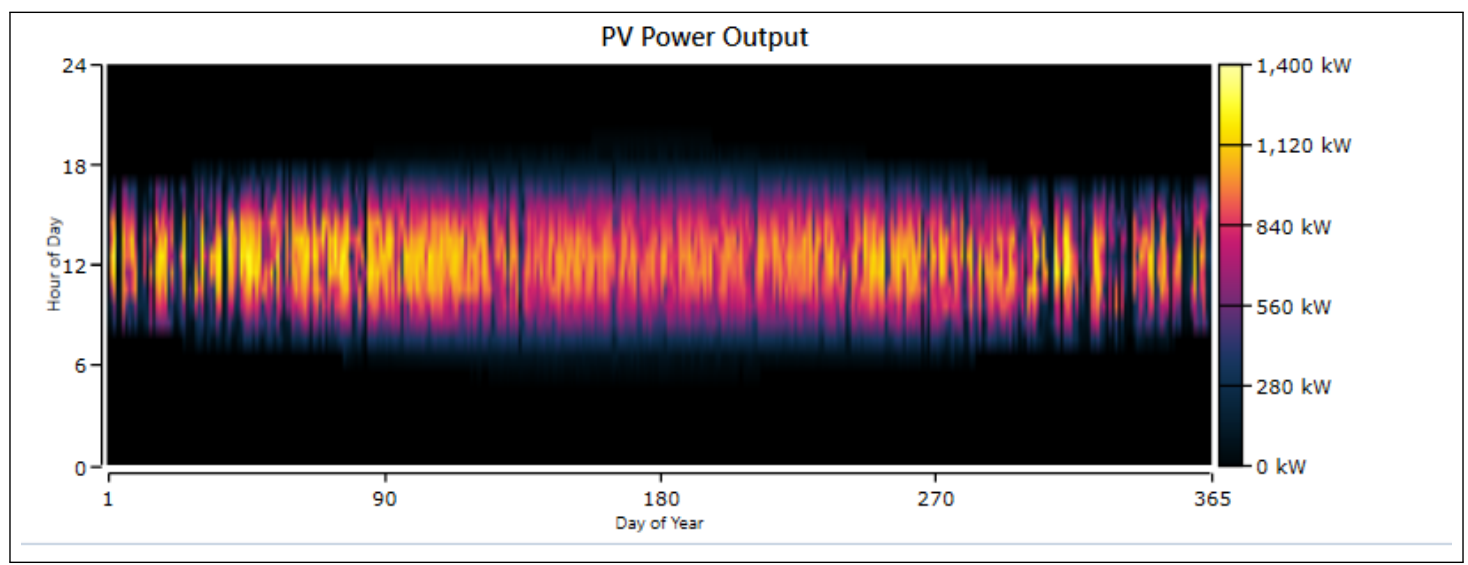

Figure 18. PV power output Case 1 and Case 2 Scenario 3.

Table 24. PV Scheme Simulation Results Case 1 and Case 2, Scenario 3.

\begin{tabular}{ccc}
\hline Quantity & Value & Units \\
\hline Rated capacity & 1450 & $\mathrm{~kW}$ \\
\hline Minimum Output & 0 & $\mathrm{~kW}$ \\
\hline Maximum Output & 1285 & $\mathrm{~kW}$ \\
\hline Mean Output & 273 & $\mathrm{~kW}$ \\
\hline Mean Output & 6549 & $\mathrm{kWh} / \mathrm{d}$ \\
\hline Capacity Factor & 18.8 & $\%$ \\
\hline Total Production & $2,390,365$ & $\mathrm{kWh} / \mathrm{year}$ \\
\hline PV Penetration & 189 & $\%$ \\
\hline Hours of Operation & 4386 & $\mathrm{~h} / \mathrm{year}$ \\
\hline Levelized Cost & 0.0343 & $€ / \mathrm{kWh}$ \\
\hline
\end{tabular}

Table 25. Aeolos-H (10 kW) Scheme Simulation Results Case 1 Scenario 3.

\begin{tabular}{ccc}
\hline Quantity & Value & Units \\
\hline Rated capacity & 70 & $\mathrm{~kW}$ \\
\hline Minimum Output & 0 & $\mathrm{~kW}$ \\
\hline Maximum Output & 96.6 & $\mathrm{~kW}$ \\
\hline Mean Output & 29.8 & $\mathrm{~kW}$ \\
\hline Capacity Factor & 42.6 & $\mathrm{kWh} / \mathrm{year}$ \\
\hline Total Production & 261,025 & $\%$ \\
\hline Wind Penetration & 20.7 & $\mathrm{~h} / \mathrm{year}$ \\
\hline Hours of Operation & 7374 & $€ / \mathrm{kWh}$ \\
\hline Levelized Cost & 0.0506 &
\end{tabular}




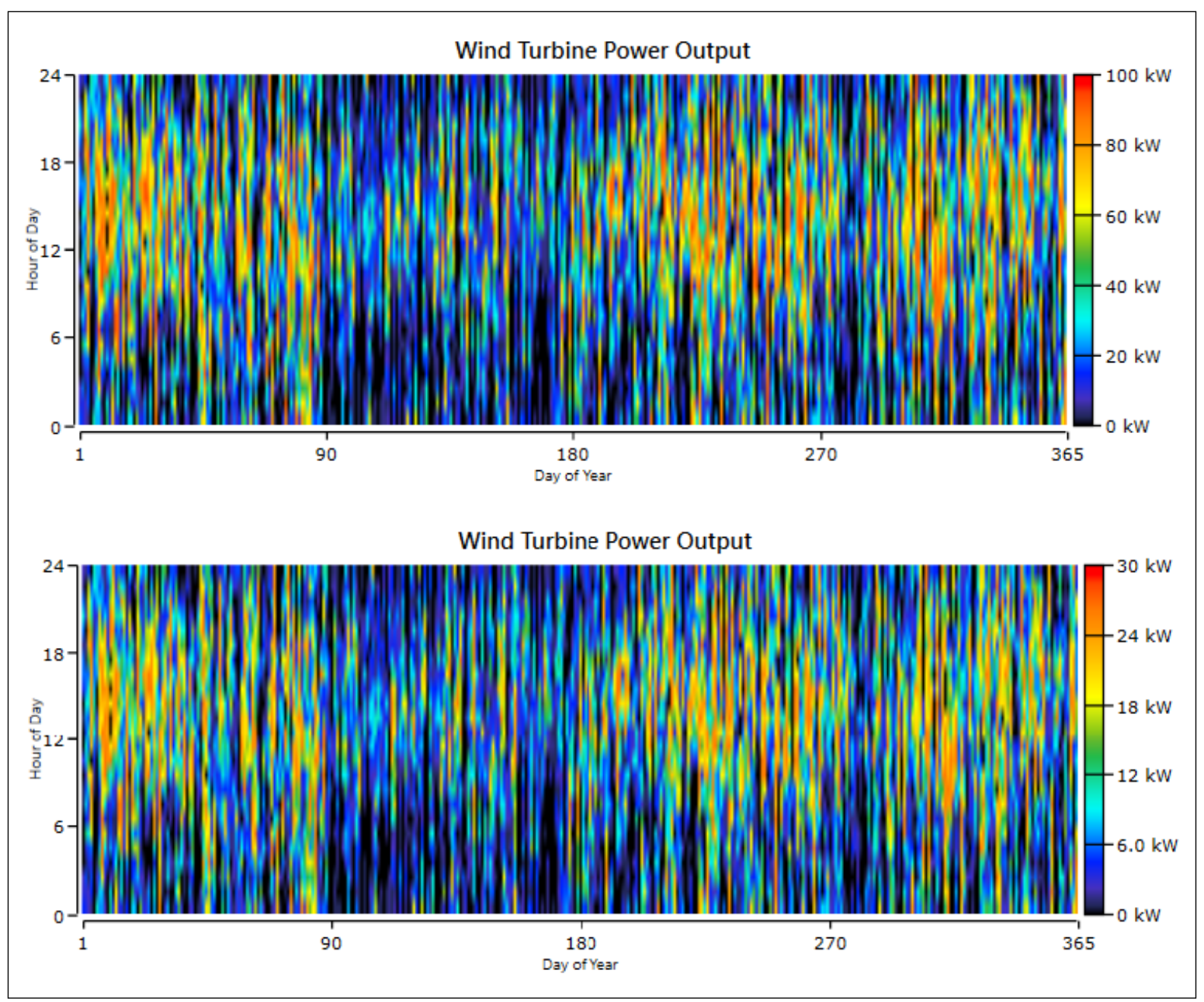

Figure 19. Wind power output Case 1 (upper figure) and Case2 (bottom figure) Scenario 3.

Table 26. Aeolos-H (10 kW) Scheme Simulation Results Case 2 Scenario 3.

\begin{tabular}{ccc}
\hline Quantity & Value & Units \\
\hline Rated capacity & 20 & $\mathrm{~kW}$ \\
\hline Minimum Output & 0 & $\mathrm{~kW}$ \\
\hline Maximum Output & 27.6 & $\mathrm{~kW}$ \\
\hline Mean Output & 8.51 & $\mathrm{~kW}$ \\
\hline Capacity Factor & 42.6 & $\%$ \\
\hline Total Production & 74,579 & $\mathrm{kWh} /$ year \\
\hline Wind Penetration & 5.90 & $\%$ \\
\hline Hours of Operation & 7374 & $\mathrm{~h} /$ year \\
\hline Levelized Cost & 0.0506 & $€ / \mathrm{kWh}$ \\
\hline & &
\end{tabular}


Another parameter for the two optimal hybrid systems for Scenario 3 is the battery. In case 11260 units of Hoppecke 24 OPzS 3000 and in case 22112 units of battery were included with days of autonomy 3 for Case 1 and 5 for Case 2. More battery units offer more autonomy, flexibility and stability. In Figure 20 State-of-Charge for each case is highlighted. Battery scheme simulation results can be seen in Tables 27 and 28. In both cases the battery units stay at medium to low levels of charge during summer months until September and are discharged to minimum (30\%) during the peak load period.

Table 27. Battery Scheme Simulation Results Case 1 Scenario 3.

\begin{tabular}{ccc}
\hline Quantity & Value & Units \\
\hline Batteries & 1260 & qty \\
\hline String Size & 12.0 & batteries \\
\hline Strings in Parallel & 105 & strings \\
\hline Bus Voltage & 24.0 & $\mathrm{~V}$ \\
\hline Autonomy & 43.7 & $\mathrm{~h}$ \\
\hline Storage Wear Cost & 0.0895 & $€ / \mathrm{kWh}$ \\
\hline Nominal Capacity & 9008 & $\mathrm{kWh}$ \\
\hline Usable Nominal Capacity & 6306 & $\mathrm{kWh}$ \\
\hline Energy In & 678,208 & $\mathrm{kWh} /$ year \\
\hline Energy Out & 583,614 & $\mathrm{kWh} /$ year \\
\hline Storage Depletion & 383 & $\mathrm{kWh} /$ year \\
\hline Losses & 94,977 & $\mathrm{kWh} /$ year \\
\hline Annual Throughput & 629,327 & $\mathrm{kWh} /$ year
\end{tabular}

Table 28. Battery Scheme Simulation Results Case 2 Scenario 3.

\begin{tabular}{ccc}
\hline Quantity & Value & Units \\
\hline Batteries & 2112 & qty \\
\hline String Size & 12.0 & batteries \\
\hline Strings in Parallel & 176 & strings \\
\hline Bus Voltage & 24.0 & $\mathrm{~V}$ \\
\hline Autonomy & 73.3 & $\mathrm{~h}$ \\
\hline Storage Wear Cost & 0.0895 & $€ / \mathrm{kWh}$ \\
\hline Nominal Capacity & 15,099 & $\mathrm{kWh}$ \\
\hline Usable Nominal Capacity & 10,569 & $\mathrm{kWh}$ \\
\hline Energy In & 783,923 & $\mathrm{kWh} /$ year \\
\hline Energy Out & 674,837 & $\mathrm{kWh} /$ year \\
\hline Storage Depletion & 715 & $\mathrm{kWh} /$ year \\
\hline Losses & 109,801 & $\mathrm{kWh} /$ year \\
\hline Annual Throughput & 727,696 & $\mathrm{kWh} /$ year
\end{tabular}




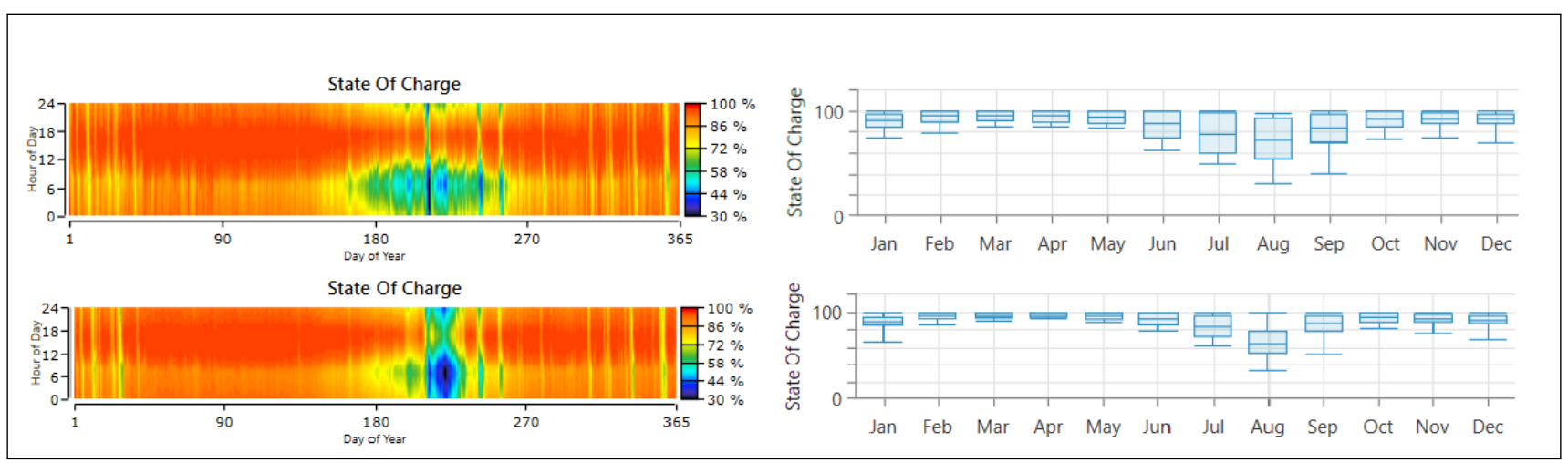

Figure 20. Battery State-of-Charge Case 1 (upper) and Case 2 (bottom) Scenario 3.

Technical difficulties are not the only obstacles that a $100 \%$ renewable hybrid system could face. Infrastructure costs are important and the implementation of high capacities of RES for the satisfaction of the load of a small island would result in high costs and expenses. First, the NPC is at 3,759,814.85€ and LCoE at $0.2241 €$ for case 1 while for case 2 NPC is $5,217,030.15 €$ and LCoE is $0.3107 €$. Compared to NPC and LCoE costs of the previous scenarios case 1 of Scenario 3 has lower costs than Scenario 1 and Scenario 2. On the other hand, Case 2 is the most expensive scenario. Tables 29 and 30 summarize the financial aspects of the optimal configuration of the two study cases of Scenario 3. In both cases the main core of costs of the system is the Capital cost and then the Operating and Maintenance Cost. The Capital cost for Case 2 is clearly higher due to the greater capacity of battery. In comparison with Scenario 1 and Scenario 2 Capital Cost is much higher and this is due to the increase in capacity of RES. Operating and Maintenance costs in Scenario 3 are of a great share in the total NPC cost $(1,157,673.37 €$ Case 1 and 1,688,118.57 $€)$. Cash flow by cost type during the lifetime of the project for Scenario 3 are depicted in Figure 21. Additionally, battery is the most expensive component of the hybrid system for both cases. As for Case 2, where battery units is almost double than Case 1, confirm the fact that size of the battery bank is proportional to its cost. Analytical costs for the 2 cases are highlighted in Tables 31 and 32. By examining those two figures, it is confirmed that battery bank is the most expensive component having a serious effect on the NPC of the hybrid systems. Case 1 is economically advantageous with NPC of 3,759,815€, while Case 2 with $5,217,030.15 €$ of NPC is not financially feasible. On the other hand, hybrid system of case 2 supports power to Donoussa's customers in a more stable way while the Excess Electricity percentage is less than in Case 1 . Nevertheless, both systems provide a $100 \%$ renewable and green solution for the electrification of Donoussa island.

Table 29. Economic characteristics of the optimal configuration of Case 1 Scenario 3.

\begin{tabular}{ccccccc}
\hline System & NPC $(€)$ & LCoE $(€)$ & Capital $(€)$ & Replacement $(€)$ & Salvage $(€)$ & O \& M $(€ /$ year) \\
\hline Optimal & $3,759,815$ & 0.2241 & $2,653,800$ & $57,900.82$ & $-109,559.34$ & $1,157,673.37$ \\
\hline
\end{tabular}

Table 30. Economic characteristics of the optimal configuration of Case 2 Scenario 3.

\begin{tabular}{ccccccc}
\hline System & NPC $(€)$ & LCoE $(€)$ & Capital $(€)$ & Replacement $(€)$ & Salvage $(€)$ & O \& M $(€ /$ year) \\
\hline Optimal & $5,217,030.15$ & 0.3107 & $3,581,700$ & $55,436.96$ & $-108,225.38$ & $1,688,118.57$ \\
\hline
\end{tabular}




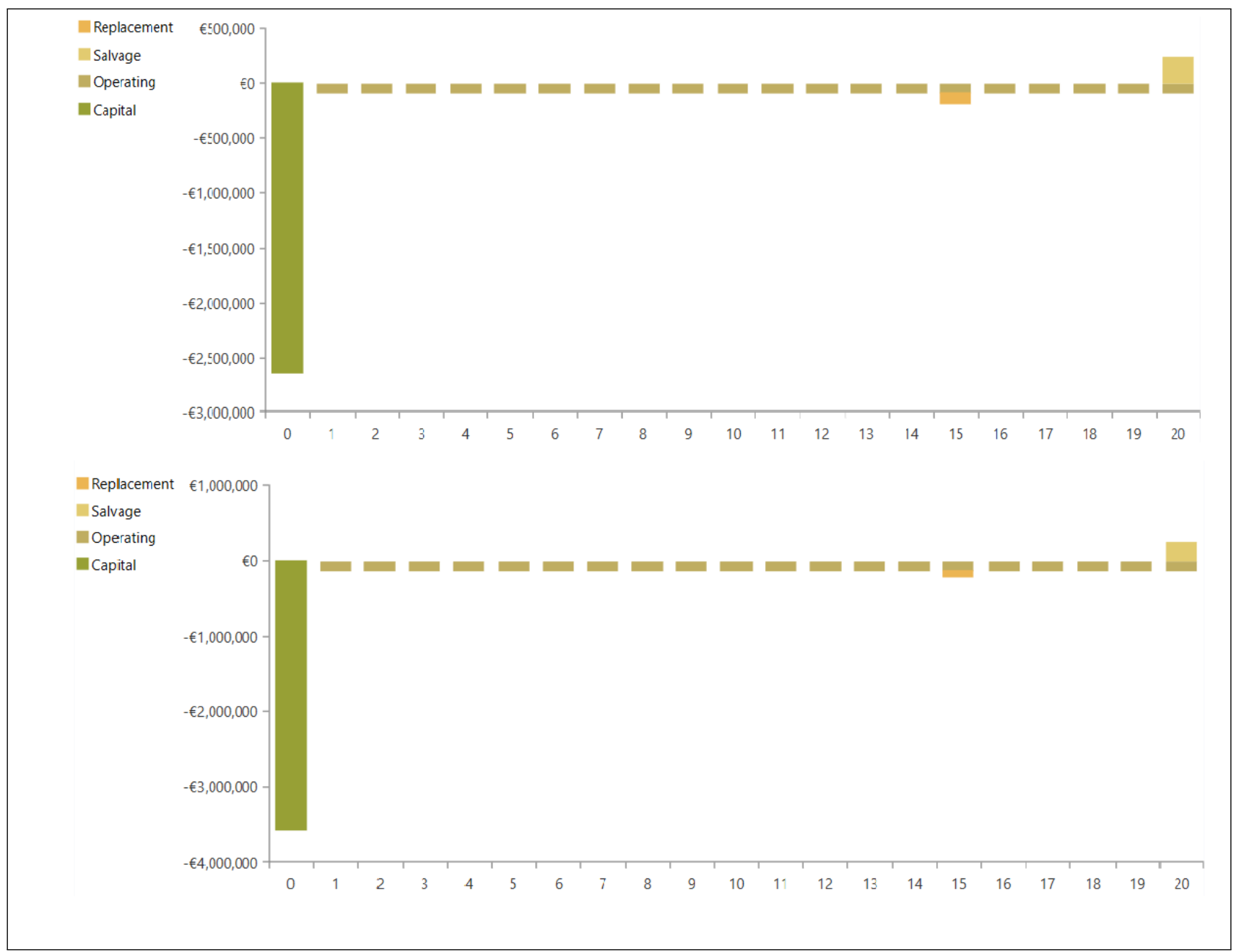

Figure 21. Cash flow summary by Cost Type Case 1 (upper) and Case 2 (bottom) Scenario 3.

Table 31. Analytical costs of each component Case 1 Scenario 3.

\begin{tabular}{ccccccc}
\hline Component & Capital $(€)$ & Replacement $(€)$ & O \& M $(€)$ & Fuel $(€)$ & Salvage $(€)$ & Total $(€)$ \\
\hline Aeolos-H 10 kW & $125,300.00$ & 0.00 & $50,252.70$ & 0.00 & 0.00 & $175,552.70$ \\
\hline Generic Flat plate PV & $899,000.00$ & 0.00 & $269,875.63$ & 0.00 & $-78,211.10$ & $1,090,664.52$ \\
\hline Generic large, free converter & $117,500.00$ & $57,900.82$ & 0.00 & 0.00 & $-31,348.24$ & $144,052.58$ \\
\hline Hoppecke 24OPzS 3000 & $1,512,000.00$ & 0.00 & $837,545.05$ & 0.00 & 0.00 & $2,349,545.05$ \\
\hline System & $2,653,800.00$ & $57,900.82$ & $1,157,673.37$ & 0.00 & $-109,559.34$ & $3,759,814.85$ \\
\hline
\end{tabular}

Table 32. Analytical costs of each component Case 2 Scenario 3.

\begin{tabular}{ccccccc}
\hline Component & Capital $(€)$ & Replacement $(€)$ & O \& M (€) & Fuel $(€)$ & Salvage $(€)$ & Total $(€)$ \\
\hline Aeolos-H 10 kW & $35,800.00$ & 0.00 & $14,357.92$ & 0.00 & 0.00 & $50,157.92$ \\
\hline Generic Flat plate PV & $899,000.00$ & 0.00 & $269,875.63$ & 0.00 & $-78,211.10$ & $1,090,664.52$ \\
\hline Generic large, free converter & $112,500.00$ & $55,436.96$ & 0.00 & 0.00 & $-30,014.27$ & $137,922.69$ \\
\hline Hoppecke 24OPzS 3000 & $2,534,400.00$ & 0.00 & $1,403,885.03$ & 0.00 & 0.00 & $3,938,285.03$ \\
\hline System & $3,581,700.00$ & $55,436.96$ & $1,688,118.57$ & 0.00 & $-108,225.38$ & $5,217,030.15$ \\
\hline
\end{tabular}

\subsection{Optimal System Configurations}

The optimal system configuration of each scenario can be easily seen in the Table 33 . It can be easily derived from Table 33 that configuration of Scenario 2 is the optimal 
result of this paper in relation to the Excess Electricity rate, the NPC and LCoE. More specifically Excess Electricity rate is $0 \%$ with a Renewable Fraction of $51 \%$, NPC around 4.03 Millions $€$ and LCoE almost at $0.240 €$. Renewable fraction is higher than RF in Scenario $1(20.2 \%)$ and lower than in the 2 cases of Scenario 3. The Excess Electricity rate is at $0 \%$ which is the desired percentage. NPC and LCoE of Scenario 2 are lower than Scenario 1 (4.95 Millions $€$ and $0.295 €$ respectively) and Case 2 of Scenario 3 (5.22 Millions $€$ and $0.311 €$ respectively). Case 1 of Scenario 3 is more economically effective than in Scenario 2. On the other hand, this system configuration faces problems due to the high percentage of the Excess Electricity rate (46.8\%). Consequently, the system configuration of the hybrid system of Scenario 2 is the optimal for the satisfaction of the load of the island.

The optimal hybrid system configuration of Scenario 2 succeeds in $0 \%$ Excess Electricity rate with a $51 \%$ of renewable integration which is a satisfying percentage for Excess Electricity in comparison to [3] where Excess Energy for the 2 scenarios examined for the island of Agios Efstratios island are $37.1 \%$ and $48.1 \%$. Moreover, in comparison to [14], the optimal system of our paper has $0 \%$ of Excess Electricity with a higher load demand. NPC cost, LCoE and Excess electricity rate of the proposed hybrid energy system of this study is better percentagewise than [30,31], our study proposes hybrid systems scenarios with a lower percentage of Excess Electricity rate. Donoussa island with a population of 167 has higher energy demands from most of the cases that were presented above and has great fluctuations in the load demand due to high tourism during the summer months.

Table 33. Optimal systems configurations of the 3 Scenarios.

\begin{tabular}{|c|c|c|c|c|c|c|c|c|c|c|c|c|c|c|}
\hline •?口: & $\underset{z}{\underset{z}{z}}$ & 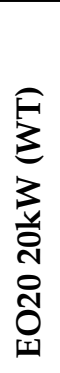 & 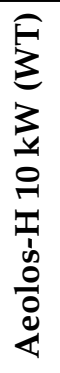 & 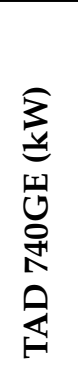 & 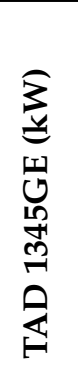 & 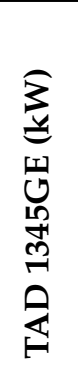 & 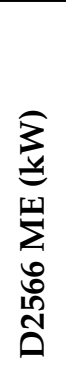 & 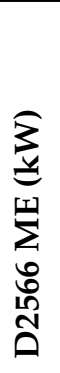 & 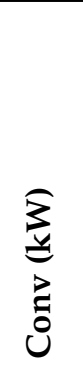 & 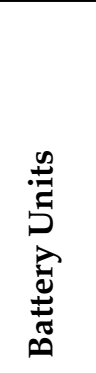 & 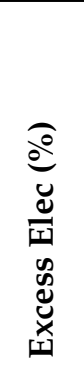 & 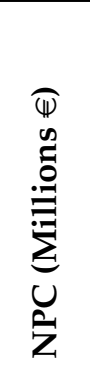 & $\begin{array}{l}\underset{\Psi}{\mathbb{W}} \\
\stackrel{\underline{U}}{0}\end{array}$ & 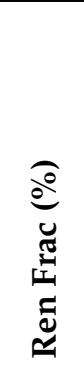 \\
\hline Scenario 1 & 100 & 2 & - & 200 & 250 & 250 & 80 & 80 & 80 & - & 6.68 & 4.95 & 0.295 & 20.2 \\
\hline Scenario 2 & 260 & 2 & 2 & 200 & 250 & - & 80 & - & 200 & 420 & 0 & 4.03 & 0.240 & 51.0 \\
\hline Scenario 3 Case 1 & 1450 & 2 & 2 & - & - & - & - & - & 470 & 1260 & 46.8 & 3.76 & 0.224 & 100 \\
\hline Scenario 3 Case 1 & 1450 & - & 2 & - & - & - & - & - & 470 & 2112 & 41.8 & 5.22 & 0.311 & 100 \\
\hline
\end{tabular}

\section{Conclusions}

In this work we explored the possibility of the operation of a hybrid renewable energy system in Donoussa island which could supply the consumers reliably and would lower the dependence from the conventional power units and fossil fuels on the island. Three main scenarios were implemented with different renewable adoption rate $(20 \%, 50 \%$ and $100 \%$ ). Gradually, conventional units of the existing power system were reduced in each scenario. Several techno-economical analyses were performed with the help of the HOMER software. The optimal hybrid system for each scenario was chosen with minimum Excess Electricity percentage and the optimized NPC and LCoE as criteria. The main principle of the study was the continuous satisfaction of load demand and the investigation for a technically and economically feasible solution with a hybrid system for a lifetime of 20 years. The Optimal system scenario was the hybrid system proposed for Scenario 2 with $0 \%$ of Excess Electricity and NPC at 4,031,102.03 $€$ and LCoE at $0.2401 €$. Similar results, percentagewise, are observed in other studies $[3,14,30,31]$. The investigation that was conducted here could be used as a basis for future work. For instance an interconnection of the Donoussa island power system to the mainland electrical grid could further increase 
the reliability of the system, while lowering the cost of electricity on that remote island and this is a scenario worth exploring further.

Author Contributions: The main idea of this paper was proposed by M.K. M.K., D.B., A.D., I.P.P. and L.T. contributed to the data analysis and writing of the final manuscript. All authors read and approved the final manuscript.

Funding: This research received no external funding.

Institutional Review Board Statement: Not applicable.

Informed Consent Statement: Not applicable.

Data Availability Statement: Data available in a publicly accessible repository. The data presented in this analysis are openly avaible in HEDNO at [https: / / www.deddie.gr/en/, (accessed on 20 July 2019)], reference number [32].

Conflicts of Interest: The authors declare no conflict of interest.

\section{References}

1. Katsoulakos, N.M. An Overview of the Greek Islands' Autonomous Electrical Systems: Proposals for a Sustainable Energy Future. Smart Grid Renew. Energy 2019, 10, 55-82. [CrossRef] [CrossRef]

2. Giatrakos, G.; Tsoutsos, T.; Mouchtaropoulos, P.; Naxakis, G.; Stavrakakis, G. Sustainable energy planning based on a stand-alone hybrid renewable energy/hydrogen power system: Application in Karpathos island, Greece. Renew. Energy 2009, 34, $2562-2570$. [CrossRef] [CrossRef]

3. Thomas, D.; Deblecker, O.; Ioakimidis, C.S. Optimal design and techno-economic analysis of an autonomous small isolated microgrid aiming at high RES penetration. Energy 2016, 116, 364-379. [CrossRef] [CrossRef]

4. Kapsali, M.; Anagnostopoulos, J.; Kaldellis, J. Wind powered pumped-hydro storage systems for remote islands: A complete sensitivity analysis based on economic perspectives. Appl. Energy 2012, 99, 430-444. [CrossRef] [CrossRef]

5. Katsaprakakis, D.A.; Voumvoulakis, M. A hybrid power plant towards $100 \%$ energy autonomy for the island of Sifnos, Greece. Perspectives created from energy cooperatives. Energy 2018, 161, 680-698. [CrossRef] [CrossRef]

6. Bertsiou, M.; Feloni, E.; Karpouzos, D.; Baltas, E. Water management and electricity output of a Hybrid Renewable Energy System (HRES) in Fournoi Island in Aegean Sea. Renew. Energy 2018, 118, 790-798. [CrossRef] [CrossRef]

7. Katsigiannis, Y.A.; Karapidakis, E.S. Operation of wind-battery hybrid power stations in autonomous Greek islands. In Proceedings of the 2017 52nd International Universities Power Engineering Conference (UPEC), Heraklion, Greece, 28-31 August 2017. [CrossRef]

8. Duchaud, J.L.; Notton, G.; Fouilloy, A.; Voyant, C. Wind, solar and battery micro-grid optimal sizing in Tilos Island. Energy Procedia 2019, 159, 22-27. [CrossRef] [CrossRef]

9. Arnaoutakis, N.; Kanellos, F.; Papaefthimiou, S. Combined operation, modeling and life cycle assessment of a generic hybrid power system installed in Crete. Energy Syst. 2017, 9, 343-359. [CrossRef] [CrossRef]

10. Karim, M.M.; Noman, A.T.; Imran, M.Z.A.; Anis-Uz-Zaman, M.; Rashid, H.; Mamun, K.A.A. Feasibility Analysis and a Proposal for 1.3 MW Hybrid Renewable Power Plant for Saint-Martins Island Using HOMER. In Proceedings of the 2019 International Conference on Electrical, Computer and Communication Engineering (ECCE), Cox'sBazar, Bangladesh, 7-9 February 2019; pp. 1-6. [CrossRef]

11. Rey, A.L.; Santiago, R.V.M.; Pacis, M.C. Modeling of a hybrid renewable power system for Calayan Island, Cagayan using the HOMER software. In Proceedings of the 2017 IEEE 9th International Conference on Humanoid, Nanotechnology, Information Technology, Communication and Control, Environment and Management (HNICEM), Manila, Philippines, 1-3 December 2017; pp. 1-6. [CrossRef]

12. Lal, S.; Raturi, A. Techno-economic analysis of a hybrid mini-grid system for Fiji islands. Int. J. Energy Environ. Eng. 2012, 3, 10. [CrossRef] [CrossRef]

13. Ghaithi, H.M.A.; Fotis, G.P.; Vita, V. Techno-Economic Assessment of Hybrid Energy Off-Grid System-A Case Study for Masirah Island in Oman. Int. J. Power Energy Res. 2017, 1, 103-116. [CrossRef] [CrossRef]

14. Ma, T.; Yang, H.; Lu, L. A feasibility study of a stand-alone hybrid solar-wind-battery system for a remote island. Appl. Energy 2014, 121, 149-158. [CrossRef] [CrossRef]

15. Ma, T.; Javed, M.S. Integrated sizing of hybrid PV-wind-battery system for remote island considering the saturation of each renewable energy resource. Energy Convers. Manag. 2019, 182, 178-190. [CrossRef] [CrossRef]

16. Shin, Y.; Koo, W.Y.; Kim, T.H.; Jung, S.; Kim, H. Capacity design and operation planning of a hybrid PV-wind-battery-diesel power generation system in the case of Deokjeok Island. Appl. Therm. Eng. 2015, 89, 514-525. [CrossRef] [CrossRef]

17. Wicaksana, H.; Muslim, M.M.; Hutapea, S.F.; Purwadi, A.; Haroen, Y. Design, implementation and techno-economic analysis of hybrid PV-Diesel for Off-grid system in Sebira Island. In Proceedings of the 20163 rd Conference on Power Engineering and Renewable Energy (ICPERE), Yogyakarta, Indonesia, 29-30 November 2016. [CrossRef] 
18. Cozzolino, R.; Tribioli, L.; Bella, G. Power management of a hybrid renewable system for artificial islands: A case study. Energy 2016, 106, 774-789. [CrossRef] [CrossRef]

19. Kalinci, Y. Alternative energy scenarios for Bozcaada island, Turkey. Renew. Sustain. Energy Rev. 2015, 45, 468-480. [CrossRef] [CrossRef]

20. Ghenai, C.; Bettayeb, M. Modelling and performance analysis of a stand-alone hybrid solar PV/Fuel Cell/Diesel Generator power system for university building. Energy 2019, 171, 180-189. [CrossRef] [CrossRef]

21. Kumar, A.; Singh, A.R.; Deng, Y.; He, X.; Kumar, P.; Bansal, R.C. Multiyear Load Growth Based Techno-Financial Evaluation of a Microgrid for an Academic Institution. IEEE Access 2018, 6, 37533-37555. [CrossRef] [CrossRef]

22. Sharma, H.; Kaur, G. Optimization and simulation of smart grid distributed generation: A case study of university campus. In Proceedings of the 2016 IEEE Smart Energy Grid Engineering (SEGE), Oshawa, ON, Canada, 21-24 August 2016. [CrossRef]

23. Karakoulidis, K.; Mavridis, K.; Bandekas, D.; Adoniadis, P.; Potolias, C.; Vordos, N. Techno-economic analysis of a stand-alone hybrid photovoltaic-diesel-battery-fuel cell power system. Renew. Energy 2011, 36, 2238-2244. [CrossRef] [CrossRef]

24. Krishan, O.; Suhag, S. Techno-economic analysis of a hybrid renewable energy system for an energy poor rural community. $J$. Energy Storage 2019, 23, 305-319. [CrossRef] [CrossRef]

25. Singh, S.S.; Fernandez, E. Modeling, size optimization and sensitivity analysis of a remote hybrid renewable energy system. Energy 2018, 143, 719-731. [CrossRef] [CrossRef]

26. Fantidis, J.G.; Bandekas, D.V.; Vordos, N. Study of a Wind/PV/Battery hybrid system-Case study at Plaka in Greece. J. Eng. Sci. Technol. Rev. 2015, 8, 6-11. [CrossRef] [CrossRef]

27. Muh, E.; Tabet, F. Comparative analysis of hybrid renewable energy systems for off-grid applications in Southern Cameroons. Renew. Energy 2019, 135, 41-54. [CrossRef] [CrossRef]

28. Esan, A.B.; Agbetuyi, A.F.; Oghorada, O.; Ogbeide, K.; Awelewa, A.A.; Afolabi, A.E. Reliability assessments of an islanded hybrid PV-diesel-battery system for a typical rural community in Nigeria. Heliyon 2019, 5, e01632. [CrossRef] [CrossRef] [PubMed]

29. Shezan, S.; Julai, S.; Kibria, M.; Ullah, K.; Saidur, R.; Chong, W.; Akikur, R. Performance analysis of an off-grid wind-PV (photovoltaic)-diesel-battery hybrid energy system feasible for remote areas. J. Clean. Prod. 2016, 125, 121-132. [CrossRef] [CrossRef]

30. Halabi, L.M.; Mekhilef, S.; Olatomiwa, L.; Hazelton, J. Performance analysis of hybrid PV/diesel/battery system using HOMER A case study Sabah, Malaysia. Energy Convers. Manag. 2017, 144, 322-339. [CrossRef] [CrossRef]

31. Shrestha, A.; Rana, L.B.; Singh, A.; Phuyal, S.; Ghimire, A.; Giri, R.; Kattel, R.; Karki, K.; Jha, S.K. Assessment of electricity excess in an isolated hybrid energy system: A case study of a Dangiwada village in rural Nepal. Energy Procedia 2019, 160, 76-83. [CrossRef] [CrossRef]

32. HEDNO S.A. (Hellenic Electricity Distribution Network Operator S.A). Available online: https://www.deddie.gr/en/ (accessed on 20 July 2019).

33. Bank of Greece. Available online: https://www.bankofgreece.gr/ (accessed on 1 September 2019).

34. Padrón, I.; Avila, D.; Marichal, G.N.; Rodríguez, J.A. Assessment of Hybrid Renewable Energy Systems to supplied energy to Autonomous Desalination Systems in two islands of the Canary Archipelago. Renew. Sustain. Energy Rev. 2019, 101, 221-230. [CrossRef] [CrossRef] 